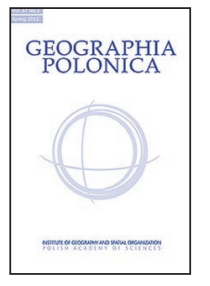

\author{
PAN \\ ivillt \\ INSTITUTE OF GEOGRAPHY AND SPATIAL ORGANIZATION \\ POLISH ACADEMY OF SCIENCES \\ www.igipz.pan.pl \\ www.geographiapolonica.pl
}

\title{
RESIDENTIAL SEGREGATION OF METROPOLITAN AREAS OF WARSAW, BERLIN AND PARIS
}

\author{
Barbara Jaczewska ${ }^{1}$ - Anna Grzegorczyk ${ }^{2}$ \\ ${ }^{1}$ Department of Political Geography and Regional Studies \\ University of Warsaw \\ Krakowskie Przedmieście 30, 00-927 Warszawa: Poland \\ e-mail: bgibki@uw.edu.pl \\ ${ }^{2}$ Department of World Regional Geography \\ University of Warsaw \\ Krakowskie Przedmieście 30, 00-927 Warszawa: Poland \\ e-mail: anna.torbicz@uw.edu.pl
}

\begin{abstract}
The aim of the work detailed in this article has been to indicate demographic and social categories to the greatest extent segregated in the three selected metropolitan areas of Warsaw, Berlin and Paris, by applying multidimensional analysis; as well as to answer a question as to whether these categories are similar or different, given the different circumstances underpinning the development of the areas under study. The metropolitan areas were selected from Central Europe (Warsaw), Western Europe (Paris), and from the area located in the borderland between these regions (Berlin). In the case of each area, typical categories were selected for analysis, and developed on the basis of accepted segregation indices (the dissimilarity index $D$, isolation index ${ }_{x}{ }_{x}$, delta index $D E L$, absolute centralisation index $A C E$, spatial proximity index $S P$ and modified location quotient $L Q_{\mathrm{p}}$ ). The multidimensional and multifaceted analysis allowed the most segregated groups at municipality and district levels to be distinguished, and presented in the context of previous research.
\end{abstract}

\section{Key words}

residential segregation $\cdot$ spatial segregation - metropolitan area $\cdot$ Warsaw $\cdot$ Berlin Paris

\section{Introduction}

Residential segregation, defined as the separate residence of different socio-economic and ethnic groups in various parts of a city, has been the subject of research within different scientific disciplines for many years. Tammaru et al. (2015:3) pointed out that studies on patterns of residential segregation had been conducted via four key phases: "the ecological approach; research on the relationship between social and spatial inequalities 
inspired by a global city thesis; studies that begin with the impact of welfare regimes on residential segregation; and, most recently, studies that emphasise the importance of the contextual embeddedness of residential segregation".

The ecological approach treated segregation as a process caused by natural forces that can be seen in all cities and create similar spatial structures. Researchers associated with the Chicago School developed a human ecology framework of invasion and succession to justify the evolving segregation patterns observable in cities (Park et al. 1925), and an important toolbox of segregation indices that were and still are used in segregation research (Massey \& Denton 1988; Marcińczak 2013); also in GIS-based studies of segregation and advanced spatial modelling (Wong 2003; Sadahiro \& Hong 2013).

The rise in income inequalities that started in the 1980s in developed capitalist countries contributed to increased interest in the relationship between social inequalities and socio-economic segregation and the debate on the roles social polarisation or professionalisation play (Hamnett 1994; Sassen 1991). As a result of the globalisation and economic restructuring activities engaged in by the supranational corporations concentrated in large cities, and according to the global city thesis, this led to social polarisation (an increase in the number of well-paid workers in the higher-order services and low-skilled workers in the consumer services) (Sassen 1991). Others have argued that it is professionalisation, rather than polarisation, that is taking place in the global cities (Hamnett 1994).

The third phase of research derives from studies surveying the impact of welfare regimes on residential segregation. Essentially, the welfare state helps to curb residential segregation through direct reductions in social inequality, or through housing policy, or through both (Musterd \& Ostendorf 1998). The major changes in the housing sector which led to a decline in the social housing sector and an increase in home ownership, sometimes caused a rise in social polarisation and residential segregation. This was due to an overrepresentation of people of lower social status in the social housing that was built in certain parts of the city, and market-oriented development of new housing estates for middle-income and high-income population groups in favoured locations. That is why many researchers have concentrated on studies showing the consequences of liberalisation of the housing market for socio-spatial segregation (van Kempen \& Murie 2009; Musterd \& van Gent 2016).

The last group of publications refers to the specific intertwining of four major spheres influencing residential segregation:

1. the economic sphere that mainly focuses on labour market conditions and market access to housing;

2. the state sphere - redistribution that covers housing and public services allocation and local regulation regimes;

3. the social sphere (reciprocity) that includes social and family networks, churches and other local voluntary organisations, and

4. the specific and durable shape of local socio-spatial realities i.e. built environments, as well as social relations inscribed in property patterns, urban histories and ideologies.

This understanding of contextual elements is not significantly different from the 'contingencies' affecting the impact of global forces on socio-spatial urban forms proposed by Marcuse and van Kempen (2000), and elaborations on urban systems' embeddedness in wider contexts of social, institutional and economic relations (Maloutas \& Fujita 2012). The last group of studies allows for better understanding of the multidimensionality of factors affecting residential segregation.

Authors analysing the process and mechanisms underpinning residential segregation have focused on different demographic, socio-economic and ethnic categories. It should be highlighted that a significant part of the work has been concerned with ethnic and racial divisions (Duncan \& Duncan 1955; White 1983; Rhein 1998; Safi 2009; Préteceille 2012). This can be associated with 
the presence of ethnic segregation as a political issue in public debate, that is of interest to a wider audience and also to researchers. A further influence has been major interest in ethnic segregation taken by American researchers, who first developed the methodology for segregation phenomenon. Some of the work of this kind compared ethnic and social forms of segregation, as these two categories are often correlated (Rhein 1998; Préteceille 2012). Analysis of the multidimensional diversity to the distribution of groups of residents resulting from demographic and socio-economic features, including education (Węcławowicz 1998; Sýkora 1999; Maurin 2004; Kovacs 2012), level of income (Sýkora 1999; Kovacs 2012), and affiliation to professional and social groups (Lajoie 1998; Sýkora 1999; Préteceille 2006; Préteceille 2012) was only presented much less frequently. It can be noted that the work of the Central European researchers has paid more frequent attention to educational categories, while French researchers focus on socio-professional categories, and Germans on welfare support categories. According to the sociological literature, professional categories combine both an income-related and an educational dimension to social status, and hence can be regarded as a synthetic measure (Słomczyński 1989), albeit of limited utility (for example in Poland), due to a lack of data. ${ }^{1}$ Generally, authors focus on particular social categories separately, or alternatively they combine only a few categories. It is frequent for the correlation between them to be investigated. An example of a study that presented multidimensional analysis i.e. more social categories concerned socio-spatial analysis in relation to the type of housing inhabited in Warsaw, in which different demographic, socio-economic, migration and housing categories were tested by Smętkowski (2009). Such analyses of different demographic and social categories in relation to the housing

\footnotetext{
1 Data for professional categories are only available for cities and their districts, not for gminas in a metropolitan area.
}

sector were presented by the Warsaw Atlas publication series (Atlas Warszawy), the previous one comparing data from the 2002 population census (Stępniak et al. 2009). These two publications pointing to the multidimensional nature of segregation do not use multidimensional segregation measures (like the dissimilarity index $D$, isolation index ${ }_{x} P_{x^{\prime}}$ delta index $D E L$, absolute centralization index $A C E$, spatial proximity index $S P$ and modified location quotient $L Q_{p}$ ) as methods of analysis, thus the work described in this text fills this niche.

The work presented in this article fits into the traditional mainstream of research on segregation and should be treated as an introduction to a more contextual approach. Hence, the aim is to indicate demographic and social categories to the greatest extent segregated in the three selected metropolitan areas of Warsaw, Berlin and Paris, by applying multidimensional analysis, as well as to answer a question as to whether these social categories are similar or different, taking into account the different circumstances underpinning the development of the areas under study. Simultaneously, the research considers whether metropolitan areas are more polarised socially than the city itself. The metropolitan areas were chosen to represent Central Europe (Warsaw), Western Europe (Paris) and an area located in the borderland between these regions (Berlin). The regions are very diverse; also internally. The aim of the study is thus to compare the segregation phenomenon as it occurs under different circumstances, but not to compare the areas themselves. The comparative perspective to residential segregation can distinguish universal features, as well as those that are exclusive to the areas analysed.

Changes taking place in cities of Central and Eastern Europe are usually shown by comparisons of cities' socio-spatial patterns under communism and after 1989 (Sýkora 1999; Berent 2007; Kovacs 2012). Hence literature on segregation in Warsaw and other Polish cities forms part of the stream of work concerning changes in 
post-communist cities (Węcławowicz 1979, 1998, 2004, 2008; Jałowiecki 2000; Smętkowski 2009; Marcińczak 2013; Górczyńska 2014). These analyses search for similarities and differences between particular countries where socio-spatial patterns are concerned, and indicate various factors lying behind these differences. The results reveal growing social inequality and transformations of the housing system in recent decades. Due to increasing social polarisation and the existing real threat of social exclusion, the significance of segregation is growing, especially in our opinion in metropolitan regions. The extremes of the current situation in Polish cities are presented in publications analysing enclaves of both wealth (Gasior-Niemiec 2007; Gadecki 2009; Polanska 2011) and poverty (Warzywoda-Kruszyńska 2011). The question then is whether social categories, or else which ones in particular, are more segregated than demographic categories, as segregation relating to age was one of the most important factors impacting upon the distribution of particular groups in the era of the communist state (Dangschat 1985). Such a situation reflected the redistribution of apartments and construction of new residential estates. Young families with children were privileged as regards access to new apartments, with this resulting in a higher concentration of people in particular age groups in correlation with the creation of residential estates at a particular period of time ${ }^{2}$. As residential estates were built in the peripheries of cities, many young people left the central districts.

Among publications describing changes in Berlin the works of Kemper (1998a, 1998b) seem interesting. The author concentrated on the changes occurring in Berlin after reunification. Prior to the reunification of Berlin, the eastern part of the city had manifested a segregation pattern similar to that in Warsaw (relating to age and education), while

\footnotetext{
2 These dependencies were also mentioned by Kemper (1998a,1998b), when he was writing about the specific situation in the eastern part of Berlin.
}

that in West Berlin was more similar to Paris (relating to socio-economic situation or ethnicity). Processes were nevertheless less welladvanced. Kemper (1998a, 1998b) analyzed the demographic, social and ethnic structure characterising residents, and showed that segregation based on demographic characteristics is becoming less marked, while that based on ethnicity and socio-economic characteristics has been growing since the 1990s. Recent publications referring to Berlin reveal a specific intertwining of social and ethnic segregation that represents a new challenge for local authorities (Häussermann \& Kapphan 2002; Friedrichs \& Triemer 2008). As population growth in Berlin mainly reflects immigration from outside Germany (Monitoring Soziale Stadtentwicklung, 2013), it remains an interesting question whether segregation based on ethnicity will increase, or else giving way to segregation based on income differences. As most immigrants live in the city, the metropolitan area may well experience increased polarisation associated with income, and enclaves of wealth development.

Publications concerning the process of segregation in Paris highlight socio-spatial changes and the increased polarisation of the metropolitan area resulting in elitisation of city space. The higher status group's segregation increases due to the expansion of their homogeneous sector on the west of the PMA, their self-segregation trends and unwillingness to social mix policy (Maurin 2004; Préteceille 2006; Pinçon \& Pinçon-Charlot 2007; Mitchell 2011; Grzegorczyk 2013). However, as Préteceille $^{3}$ (2006) indicates, the group's attitudes towards the social mix are diversified. Publicsector professionals, researchers and professors are more spread as are professionals in the media, arts and entertainment, with the segregation decreasing due to the gentrification process (Clerval 2010). On the other hand, administration professionals and entrepreneurs are more and more subject to segregation. Blue-collar workers' segregation

\footnotetext{
${ }^{3}$ In a study based on the IRIS scale.
} 
is also increasing due to reductions in their numbers and resistance confined to the most degraded industrial areas (Préteceille 2006). Reduced segregation of immigrants between 1968 and 1999 on a district scale ${ }^{4}$ (Pan Ké Shon 2011) is accompanied by their minor presence in comparison with the French population in Sensitive Urban Zones (ZUS - zone urbaine sensible) ${ }^{5}$, and their greater access to social housing stock (Bidoux \& Virot 2011). Hence the next immigrant generation's residential pattern reveals a slow expansion, mainly within lower-status areas. Mention should also be made of immigrants' high concentrations in some neighbourhoods, particularly limited to sink estates, and inter alia reflecting discrimination on the labour and housing markets. Finally, the thesis from Préteceille (2012) and Mitchell (2011) on the politicisation of the immigrant issue and the banlieue term ethnisation present in a public discourse should be mentioned as generalisations of complex problems may cause stereotypes. The question concerns whether it is ethnic or social groups for which the segregation level is greater nowadays, as well as the importance of demographic segregation in the Paris Metropolitan Area.

\section{Methodology}

Methodology underpinning research on the phenomenon of segregation resembles the phenomenon itself in being highly diversified. In the work described in this article, the methodology consisted of the following aspects:

1. Categories covered by the analysis: As segregation was to be treated broadly,

4 Immigrants did not constitute a majority in any of the urban districts of over 5000 inhabitants in 1999, while even in smaller districts, majorities only occurred rarely.

5 ZUS (zones urbaines sensibles) - intra-urban districts created in 1996 as priority zones for urban, economic and social policies. The zones are characterised by huge housing estates and degraded buildings as well as low employment rates. The policy focus is thus on ameliorating employment prospects. There are 2 types of zone: zones de redynamisation urbaine (ZRU) and zones franches urbaines (ZFU). three different characteristics were selected: demographic (age and size of households/ families), socio-economic (education, affiliation to social and professional groups, unemployment, unearned sources of income, disability) and related to country of birth (affiliation to immigrant/foreigner groups). In each of the analysed areas the categories studied vary in line with the diversity of conditions under which they exist, but also in connection with the availability of statistical data. In conjunction with existing, diversified conditions of development and the fact that the phenomenon of segregation itself can frequently concern various social groups and attain differing levels of intensity, the cities in this article were researched separately.

2. Geographical space covered by the research: Residential segregation is analysed for the given metropolitan area and city with a view to its specificity on different scales being compared. The calculations were made separately for both the whole metropolitan areas including cities, and for the cities themselves.

3. Territorial units included in the area of research: The municipalities of the metropolitan areas and districts of the cities are analysed. The sizes of administrative units covered by the study differ sufficiently to preclude comparability. The areas analysed in the PMA comprise the greatest number of units, therefore also the smallest; while the BMA has the smallest number of (largest) units. The delimitation of the Warsaw Metropolitan Area was engaged in in line with the view taken by the Masovian Regional Planning Office and Ministry of Regional Development. The Berlin Metropolitan Area was treated very broadly, in respect of the entire Land of Berlin-Brandenburg; while the Paris region was taken to be the whole of Île-deFrance, analysed as most equivalent to the Paris Metropolitan Area. Both sizes and numbers of units analysed can obviously influence levels of segregation indices. However, the selection of units was a practical one motivated by availability of data. 
4. Segregation measures: Measures were selected following a broad review of relevant subject literature presented in Grzegorczyk and Jaczewska (2015). Ultimately, the multidimensional approach approved by Massey and Denton (1988) was selected. Analyses were conducted using the dissimilarity index $D$ (dimension of inequality), the $P_{x}$ isolation index (dimension of exposition), the DEL delta index (dimension of concentration), the ACE absolute centralization index (dimension of centralisation) and the $S P$ spatial proximity index (dimension of clustering) (Annex 1). Cartograms were developed on the basis of the calculated $L Q_{p}$ modified location quotient (Annex 2). The last two measures present the spatial dimension to the phenomenon.

In the article we presented maps of features indicative of the highest values for $L Q_{p}$ and $S P$ in respect of the selected characteristics. This reflects their manifesting the highest levels of segregation in terms of the clustering dimension.

Analysis made use of the most recent and reliable Census data, as available on the websites of statistical offices with seats in: Warsaw (for 2002), Berlin (for 2012) and Paris (for 2011). It should be noted that the Warsaw data are by far the oldest, and in addition relate to the situation prior to Poland's European Union accession. This ensured that the current situation in Warsaw could only be alluded to by means of certain additional remarks ${ }^{6}$.

\section{Social segregation in the Warsaw Metropolitan Area (WMA) and Warsaw}

The phenomenon of segregation in the Polish capital was analysed by reference to: age, family size and independent household size, education, profession (data is available only for Warsaw city), unemployment level, social benefits and disability. Among these factors

\footnotetext{
${ }^{6}$ Data from the last Census of 2011 is not reliable for administrative units at the local or 'county' levels, due to the census methodology applied.
}

applying to the WMA, it was disablement, possession of vocational education or noncompletion of primary education that yielded groups subject to the most marked separation. These factors were followed by large household size or large family, as well as the completion of higher education - the value of the dissimilarity index $D$ being nearly 0.20 (Tab. 1). The least-educated people also constitute the most isolated group $\left({ }_{a} P_{a}=0,96\right)$. In the Warsaw Metropolitan Area, the absolute centralization index attains high values among groups of educated people and households consisting of one or two people (ACE is estimated at around 0.70-0.80), and then in regard to households consisting of three people, families with 1 child and older people (ACE above 0.60) (Tab. 1). The high value of the concentration index $(D E L=0.70)$ for educated people and small households means that in reality they mostly live in the city of Warsaw.

In the case of Warsaw, it is possible to observe certain differences in the distribution of particular groups. The most distinct segregation concerns people of low social status (industrial workers, craftspeople, operators and installers) or large households (more than 4 people), as well as people aged over 60 ( $D$ up to 0.20$)^{7}$. Thereafter, vocational position stands out. The central districts are mostly resided in by the over60s, living on a pension or social support in 1- or 2-person households. For these groups the value of the ACE centralization index was above 0.50 (Tab. 1). The DEL concentration index is similar, so the same demographic and socio-economic groups are separated from the rest. Analysing the data regarding the clustering of particular groups, we can see that in concentrated areas of several districts (the SP value above 1) there are older people, one-person households, and then people receiving social support and families with 1 child or 4-people

\footnotetext{
${ }^{7}$ An exception is the professional group of farmers, who - for obvious reasons - are only present in small numbers in cities, and are very concentrated (the $D$, $D E L$ and $S P$ indices).
} 


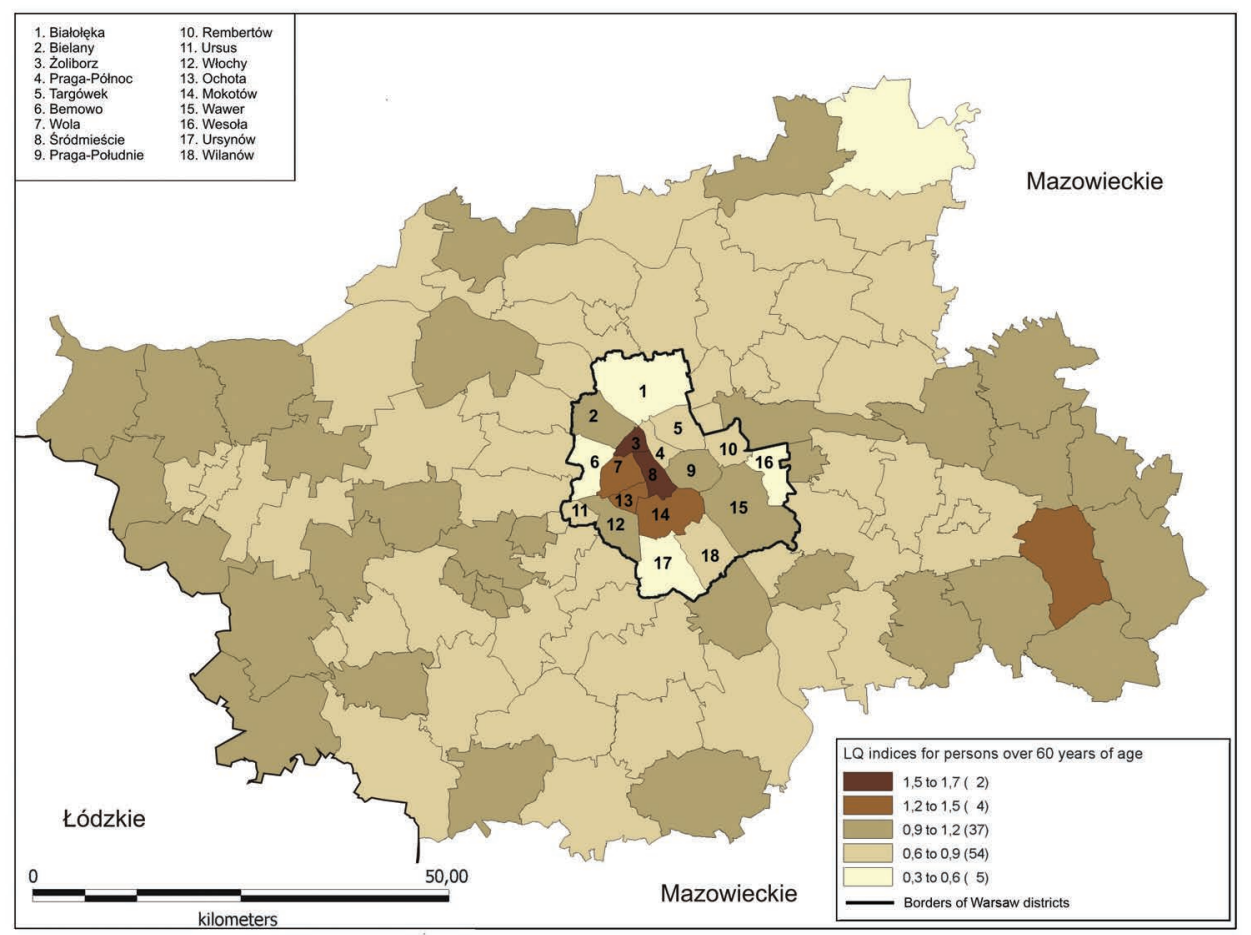

Figure 1. LQ indices for persons over 60 years of age

households (Tab. 1). The pattern described is different from the findings from previous years - segregation analysis according to education of urban units in 1988 revealed the highest segregation of the higher-education population followed by vocational education (Węcławowicz 2000), however the trends are hardly comparable due to different unit scales. Marcińczak (2013), with research based on affiliation to social and professional groups, received results more similar to ours. The highest degree of segregation concerned both high status (specialists) and low social status (industrial workers, craftspeople, operators, installers). In part, this may be explained by reference to an increase in the complexity of segregation in the post-communist era.

To analyse the spatial disparities characterising the phenomenon of segregation, data on the over-60s (Fig. 1), large households (Fig. 2) and people receiving social support in total (Fig. 3) were chosen (with these indices indicating the largest $L Q_{p}$ and $S P)^{8}$. Within the WMA the concentration of older people is visible in Warsaw, as well as in a zone approx. 100-120 km out from the city. A larger value for the $L Q_{p}$ index is observed in the western part of the WMA (approx. 1.50). In Warsaw, the largest concentration of older people (above 60 years old) is observed in the central districts, such as Śródmieście, Żoliborz, Wola and Ochota $\left(L Q_{p}\right.$ above 1.20), while the values of the index are significantly lower on the peripheries, such as Rembertów, Wesoła and Białołęka $\left(L Q_{p}\right.$ between 0.31-0.69). The value attained by the $L Q_{p}$ index for large households was the highest among the indices analysed. Within the WMA the value of the $L Q_{p}$ index was high in northern and western counties especially (exceeding 6.00). In Warsaw it was

${ }^{8}$ Significant differences can also be observed as data on education are analysed, as was described in detail and presented on maps in Grzegorczyk and Jaczewska (2015). 


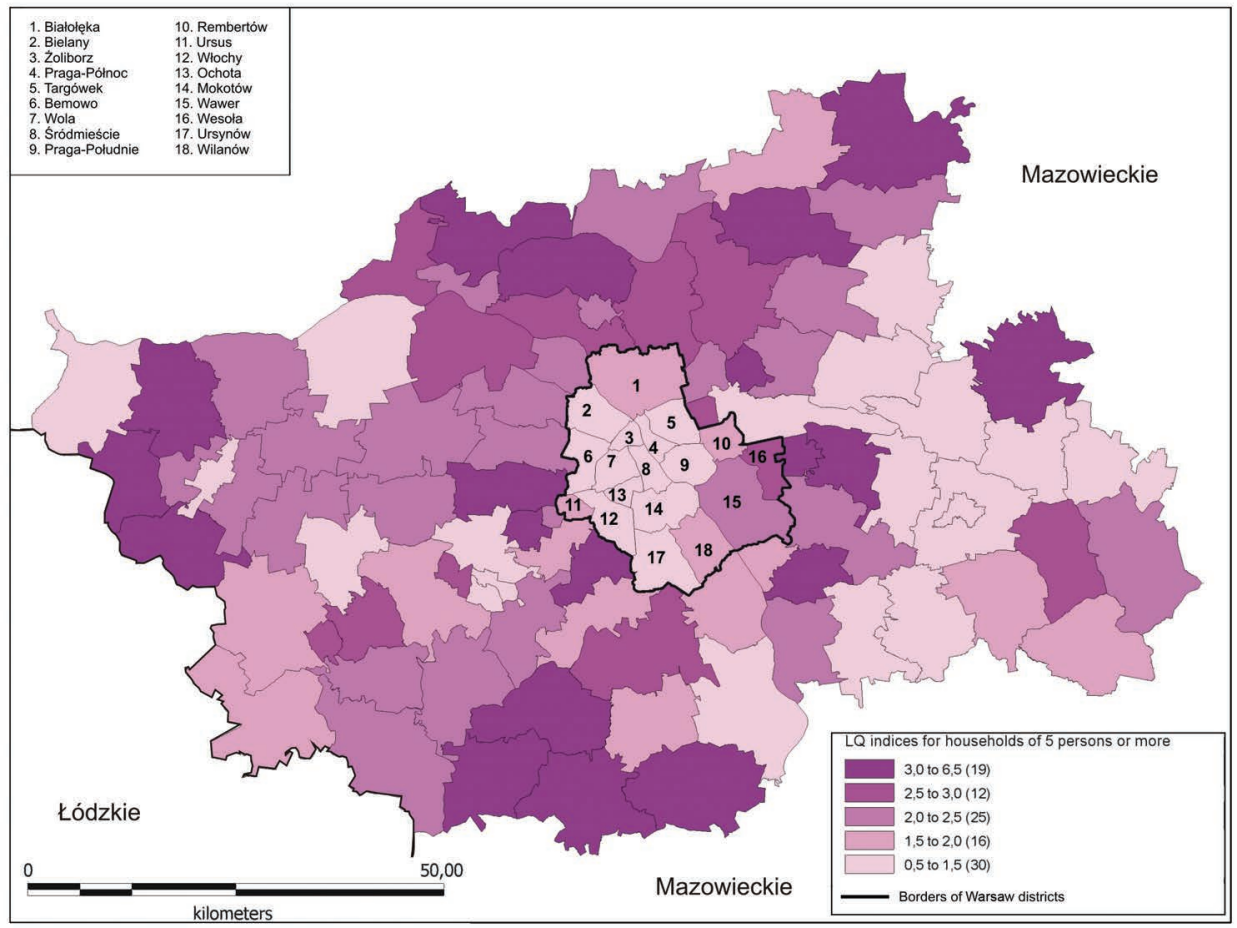

Figure 2. LQ indices for households of 5 persons or more

only peripheral districts that recorded higher values of the index (1.50-2.00). Data on $L Q_{p}$ for people receiving social support in general indicate that the highest value is observed in the western part of the WMA. In Warsaw itself, the highest value recorded for the index characterised downtown districts. It was also possible to observe a correlation between areas resided in by older people and those receiving social support.

\section{Social Segregation in the Berlin Metropolitan Area and Berlin}

In the case of the BMA and Berlin, social segregation was analysed by reference to: age, size of household, average household income, education, affiliation to professional groups, unemployment and social support, as well as affiliation to groups of foreigners. It should be underlined that the City of Berlin constitutes a dominating unit in terms of numerous factors (population, concentration of business activities or concentration of immigrants), with this obviously impacting upon the results.

The analysis of statistical data from 2012 indicates that the level of segregation within the BMA is relatively low, but still higher than in the WMA (Tab. 2). Higher values were obtained in the case of data regarding foreigners $(D=0.58)$ than professional groups (a slightly higher value was obtained for bluecollar workers, i.e. $D=0.21$ ), people receiving social support (benefits related to retirement age and inability to work, $D=0.17$ ) and education level (higher values in the group with higher education, $D=0.12$ ). Interestingly, the $D$ index assumed a rather high value of 0.33 in the case of households consisting of three people, with this being an indication of the major role these play in the BMA context. Within the BMA, a majority of the features studied display a greater concentration and centralisation than in the case of Berlin city. It is worth highlighting that the said concentration 


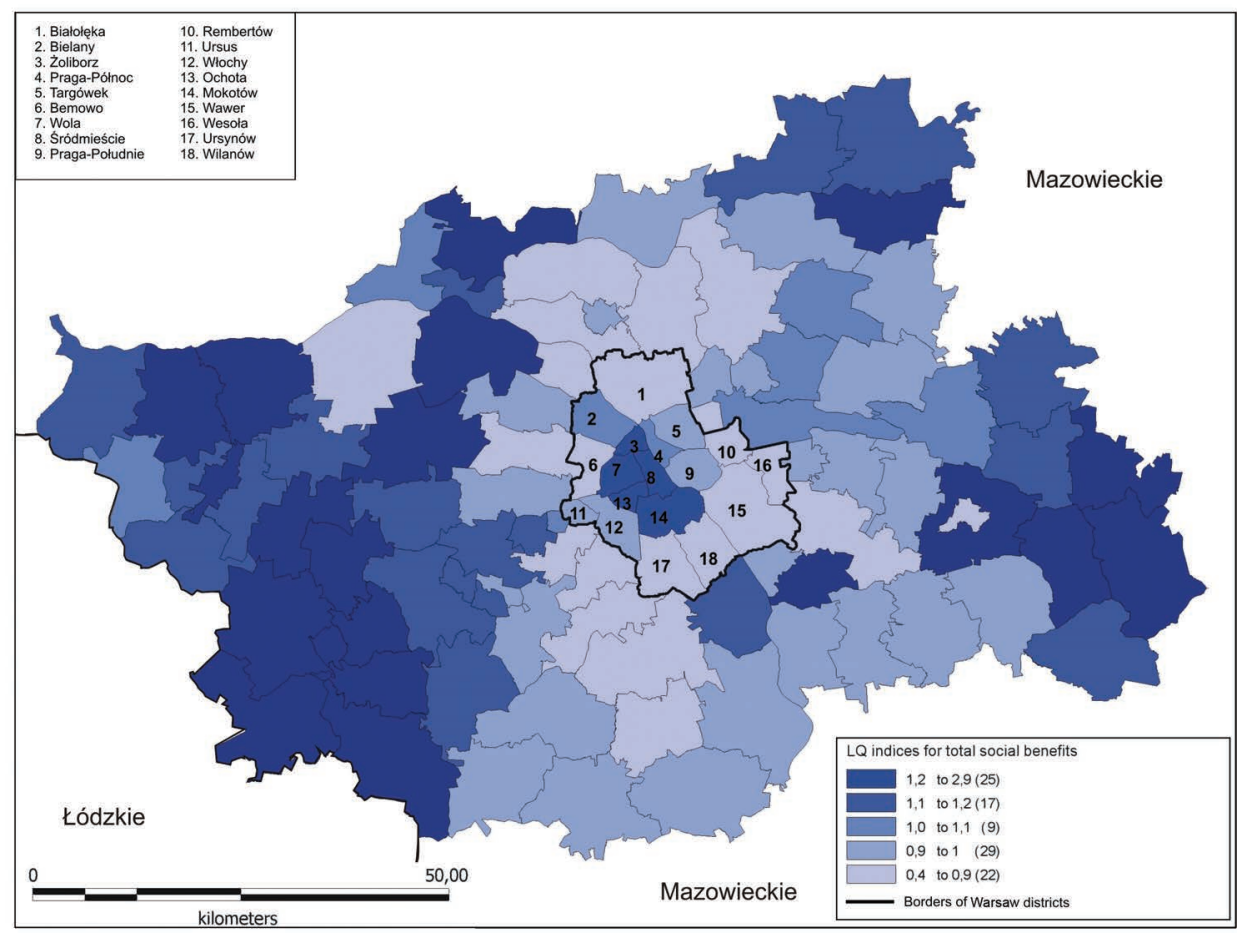

Figure 3. LQ indices for total social benefits

and centralisation indices reached high values (higher than in the city) where people aged 18-30 were concerned (DEL $=0.66$; $A C E=0.65)$, this is only going to confirm the thesis that Berlin attracts younger people who wish to study at universities or work in the city.

The isolation index presenting the probability of contact with a representative of their own group, not a different group, is higher in the case of people aged 30-50, living in one- or two-person households with an income exceeding 2600 EUR per month (the highest income group), with these people having a higher education capable of indicating how isolation mostly affects groups of the highest statusy.

In Berlin the highest segregation level also concerned ethnicity issues (for foreigners $D=0.45)$ (Tab. 2). For the city in the case of other social categories the dissimilarity index is low and indicates no segregation (if with slightly higher values for people belonging to different professional groups - mostly workers $D=0.15$ and self-employed people $D=0.11$; as well as people receiving social support - relating to a bad financial situation $D=0.14$ and people at retirement age or unable to work $D=0.12$; and unemployed people $-D=0.11$ ). Results regarding different age groups are also interesting. Rather higher values can be observed in the case of older people - above 65 years of age $(D=0.10)$ and people aged 18-30 $(D=0.09)$. Older people as a group are here not characterised by especially high concentration $(D E L=0.17)$ or centralisation $(A C E=0.14)$. The highest values for these indices are in fact obtained in the case of young people aged 18-30 (DEL $=0.28$ and $A C E=0.29)$. The isolation index in Berlin only assumes slightly higher values in the cases of highly-educated people and one-person households, with the highest income (above 2600 EUR per month) (i.e. people of high social status). There is no indication of significant differences when 


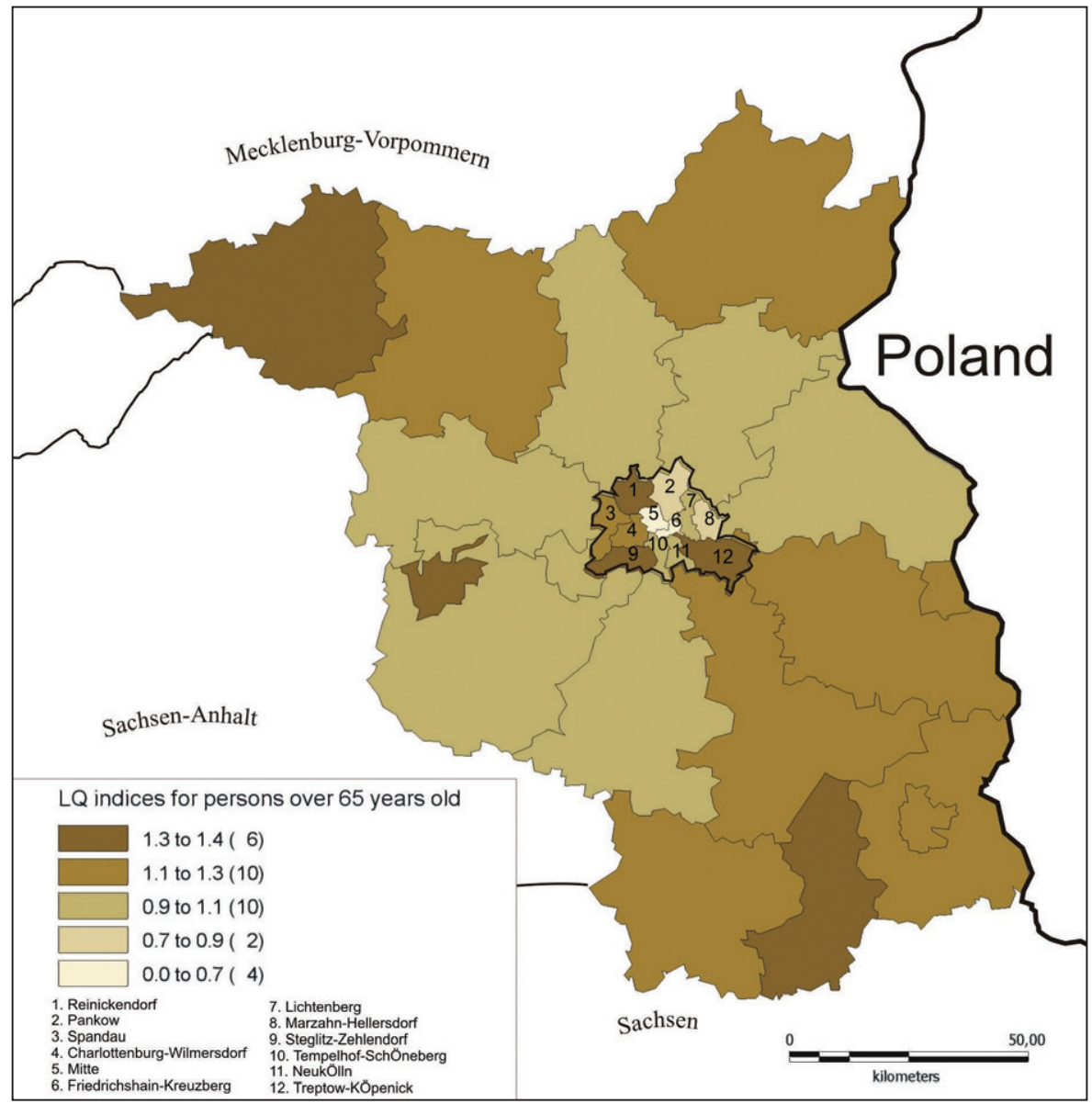

Figure4. LQ indices for persons over 65 years of age

comparisons with the metropolitan area are made. It is worth highlighting here how the $S P$ index presenting the degree to which units resided in by a particular group achieve 'neighbour' status, assumed higher values in the group encompassing 2-person households, where income is above 2600 EUR per month, as well as those resided in by people over 65 years old.

Data selected for analysis concerned: the over-65s (Fig. 4), households with an income above 2600 EUR per month (Fig. 5) and the number of foreigners(Fig. 6). The location index indicates that, within the BMA, the highest indices are observed in the peripheral counties, especially in the northern and southern parts. In Berlin the indices indicate a relatively marked concentration of older people in the western part of the city. It is easy to discern the division between the parts of the city formerly belonging to the FRG, where $L Q_{p}$ indices are higher, or the GDR, where values are lower. The $L Q_{p}$ index for households with an income above 2600 EUR per month indicates a concentration in counties adjacent to the City of Berlin. In the city itself the division between the poorer eastern and richer western parts is also visible. The maps regarding foreigners are also interesting. Within the BMA the indices assume values below 1.00 , while in the city they even reach values exceeding 1.60 (in Mitte, Neuköln 


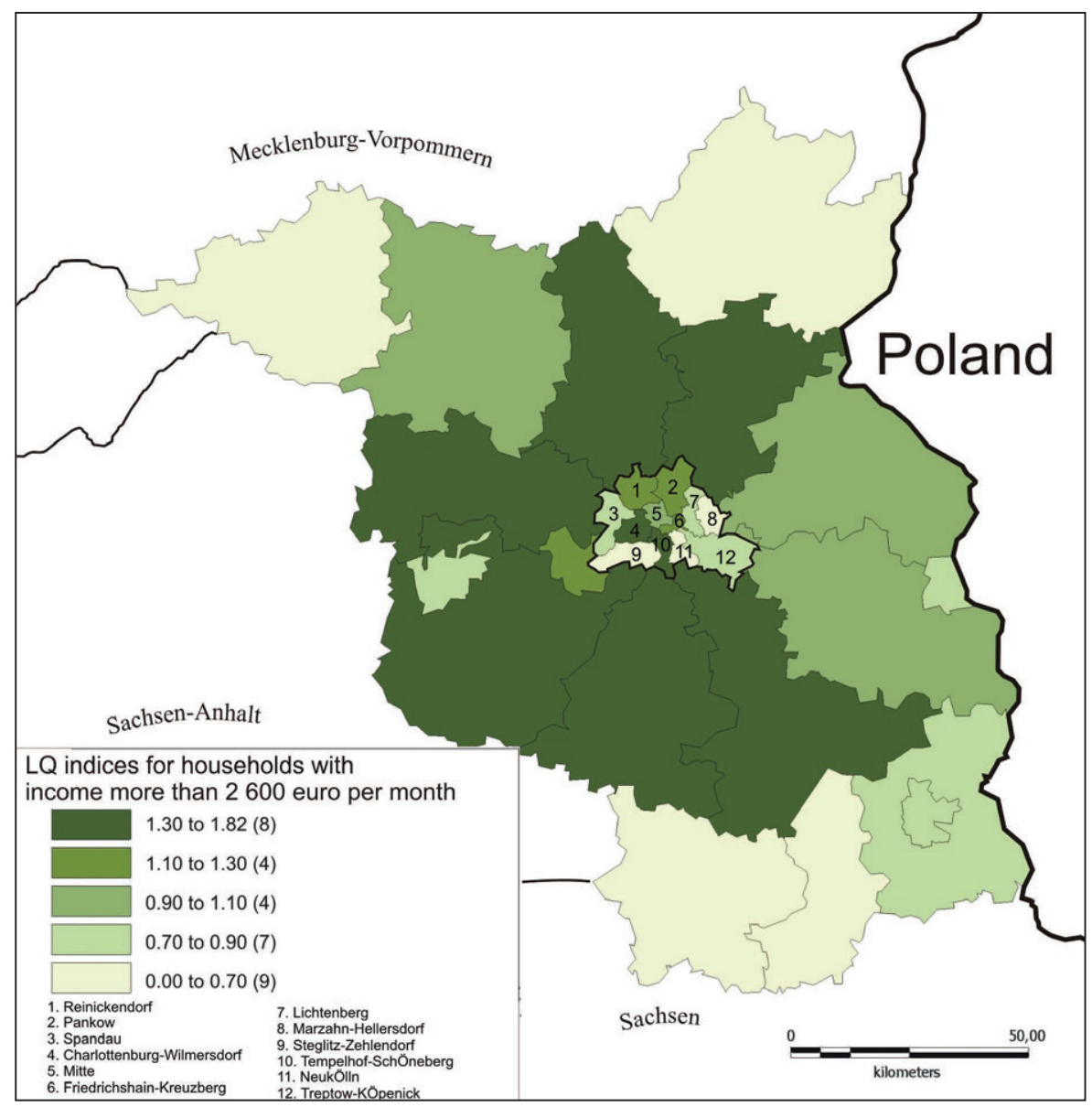

Figure 5. LQ indices for households with income of more than 2600 euro per month

and Friedrichshain-Kreuzberg). Moreover, a higher concentration of foreigners in the cities that are also counties, such as Potsdam, Cottbus or Frankfurt (Oder) can be seen. It is worth underlining that in the counties resided in by foreigners, where the $L Q_{p}$ index is the highest, income per household is at its lowest levels.

\section{Social segregation in the Paris Metropolitan Area and Paris}

In the cases of the PMA and Paris, social segregation was analysed by reference to: age and family structure, education, affiliation to social and professional groups, unemployment, affiliation to groups of immigrants and foreigners ${ }^{9}$. Higher indices were reported for the metropolitan area than for the city itself, which is more homogenous on a district scale (Tab. 3). Within the PMA the most marked segregation was observed in the case of people with higher education, executives and senior intellectual workers - the $D$ index

${ }^{9}$ An 'immigrant' is defined as a foreign person born abroad and living in France, whose status is permanent and does not depend on possible citizenship acquisition. Hence, it is the country of origin and not the nationality that defines an immigrant. A 'foreigner' is defined as a person living in France and not having French citizenship. After acquiring French citizenship, people become French by acquisition (by naturalisation, marriage or declaration) (INSEE 2012). 


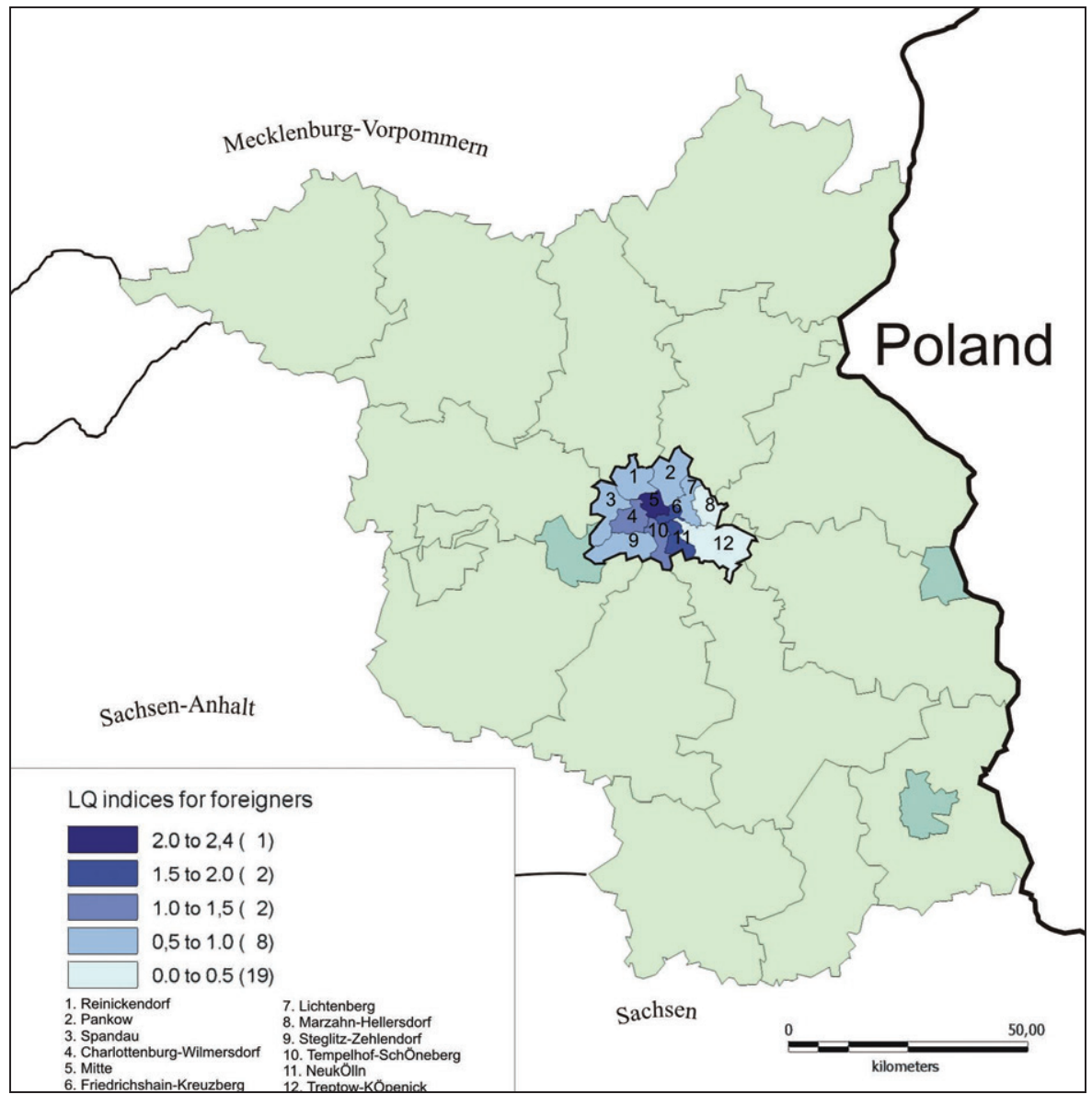

Figure 6. LQ indices for foreigners

value above 0.20 , as followed by blue-collar workers and families with 4 or more children. Hence the pattern shown by previous research is maintained. Consequently, the process of elites occupying a higher percentage of a metropolitan area than before, i.e. the so-called elitisation, is strongly visible in Paris. The disproportionally small space of the metropolitan area is resided in mainly by foreigners and immigrants, and then by people with higher education and with the highest social and professional status, and unemployed people. The isolation index attains its highest value in the case of people of the highest social and professional status, with education, and employees providing low-order services and childless families - the $P$ value is above 0.40 . Therefore segregation in the case of the PMA is a multidimensional phenomenon concerning the same social groups, which means mainly people of high social status, or else people of low social status. In the majority of dimensions to segregation (with some slight reshuffles), the indices reach their highest values in the case of the above groups. Foreigners and immigrants are in fact groups segregated to a more limited extent than either high- or low-status inhabitants. Although their places of residence are restricted to a limited space within the PMA, as is made clear by DEL index - they concentrate particularly in Seine-Saint Denis, they 
live among others on a district scale (other indices are relatively lower), and mainly with low-status groups. On the one hand, these findings confirm a downward trend for the segregation of immigrants. On the other, a high concentration in such problem areas as Saint-Denis, La Courneuve or Clichy-sousBois should also be pointed to, recalling at the same time that these areas are not representative of the Paris banlieue, which is a very diverse entity.

In Paris the most separated groups are blue-collar workers ( $D$ above 0.15 ) and people lacking education. A more-marked spatial concentration is observed in the case of these two groups (with values of the DEL index of approx. 0.30). People with higher education and of the highest social and professional status are concentrated in close proximity to the centre, and have spread to the west; their isolation indices are the highest. These groups create significant compact, homogeneous areas, which is to say that districts resided in by them are adjacent to one another (having values of $S P$ above 1). Such enclaves are also created by blue-collar workers and people without education, and then by single-parent families, families with four or more children and the groups of the over-60s and the 30-44 year-olds. The greater homogeneity of Paris is thus related to its more far-reaching elitism as compared with the metropolitan area, and especially the city centre.

With a view to the spatial aspect of the phenomenon of segregation being considered further, consideration was confined to data on: the over-60s (Fig. 7), executives and senior intellectual workers (Fig. 8) and blue-collar workers (Fig. 9) ${ }^{10}$, for which the indices $L Q_{p}$ and $S P$ attained their highest values. Although the centre of Paris has a greater concentration of older people (especially in districts $\mathrm{VI}, \mathrm{VII}$ and $\mathrm{XVI}$ ), it is particular municipalities of the metropolitan area,

10 The $L Q_{p}$ index for people from groups of different educational attainments was analyzed in the article by Grzegorczyk and Jaczewska (2015), while foreigners were addressed in Grzegorczyk (2014). within both the internal and external agglomeration rings, that are characterised by the highest concentration of all. The highest $L Q_{p}$ values for older people are to be observed in the western and southern municipalities of the external ring of the metropolitan area $\left(L Q_{p}\right.$ reaching 5.33). Simultaneously, these are areas in which people of the highest social and professional status are concentrated to the greatest extent. A clear division between the western and north-eastern parts of the metropolitan area is confirmed by the presence of highest values for the $L Q_{p}$ index - in the case of craftsmen, shopkeepers and managers approx. 14 within the PMA and 1.80 in Paris (district XVI), and in the case of specialists and blue-collar workers approx. 12 within the PMA and above 1.50 in Paris itself. The districts resided in by people of the highest status are the central ones, as well as districts $X V I$ and $X V I I$. The lowest status in turn coincides with districts XVIII, $X I X$ and XX. It should be highlighted that the analysis is conducted on a district scale that does not reveal socio-spatial change ongoing in eastern districts (i.e. XVIII, XIX and XX) as a result of a gentrification process that is increasing the homogeneity of Paris (as discussed further on in the article).

\section{Conclusions}

Multidimensional and multifaceted analysis carried out for the metropolitan areas and cities of Warsaw, Berlin and Paris allowed for the determination of the demographic and social categories most subject to segregation at county, municipality and district levels, as well as features both common and specific to particular areas. It is not possible to state explicitly that the studied metropolitan areas manifest a higher level of segregation than the cities. In the case of the PMA, the city is more homogeneous than its metropolitan area, and elitist on a district scale. In the case of the WMA and BMA, it is clear that values for the concentration and centralisation indices are significantly higher than in the case of the respective cities, while the dissimilarity 


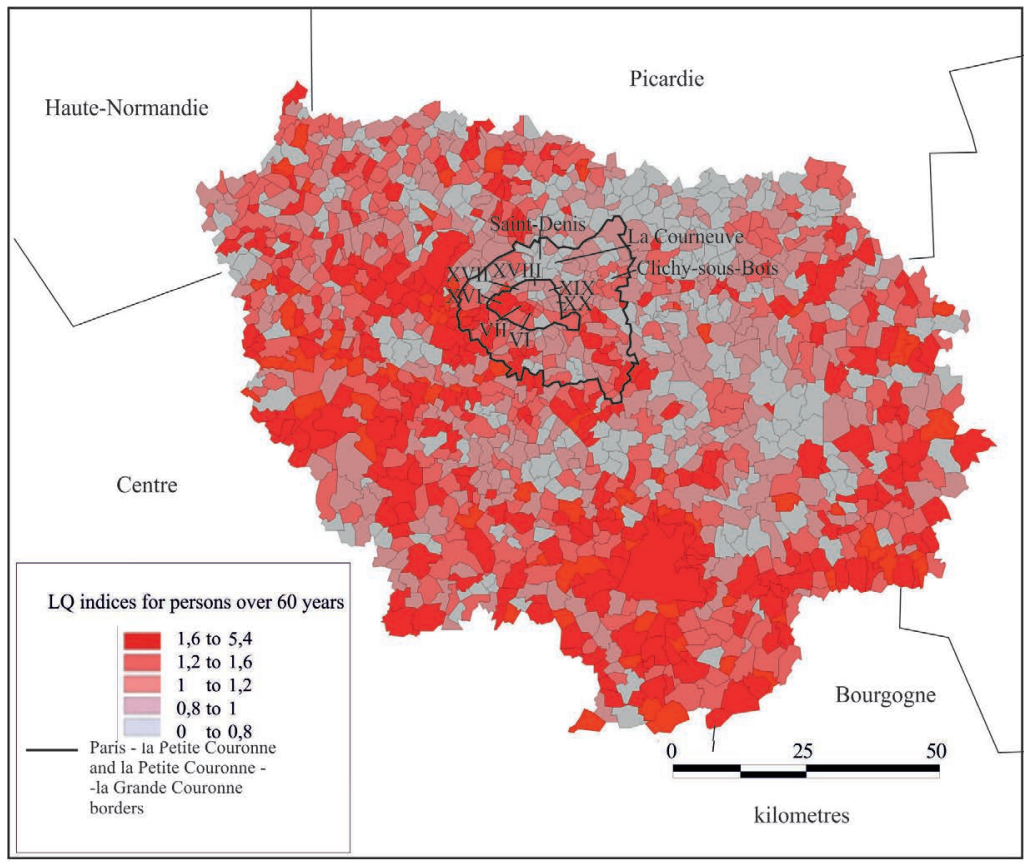

Figure 7. LQ indices for persons over 60 years of age

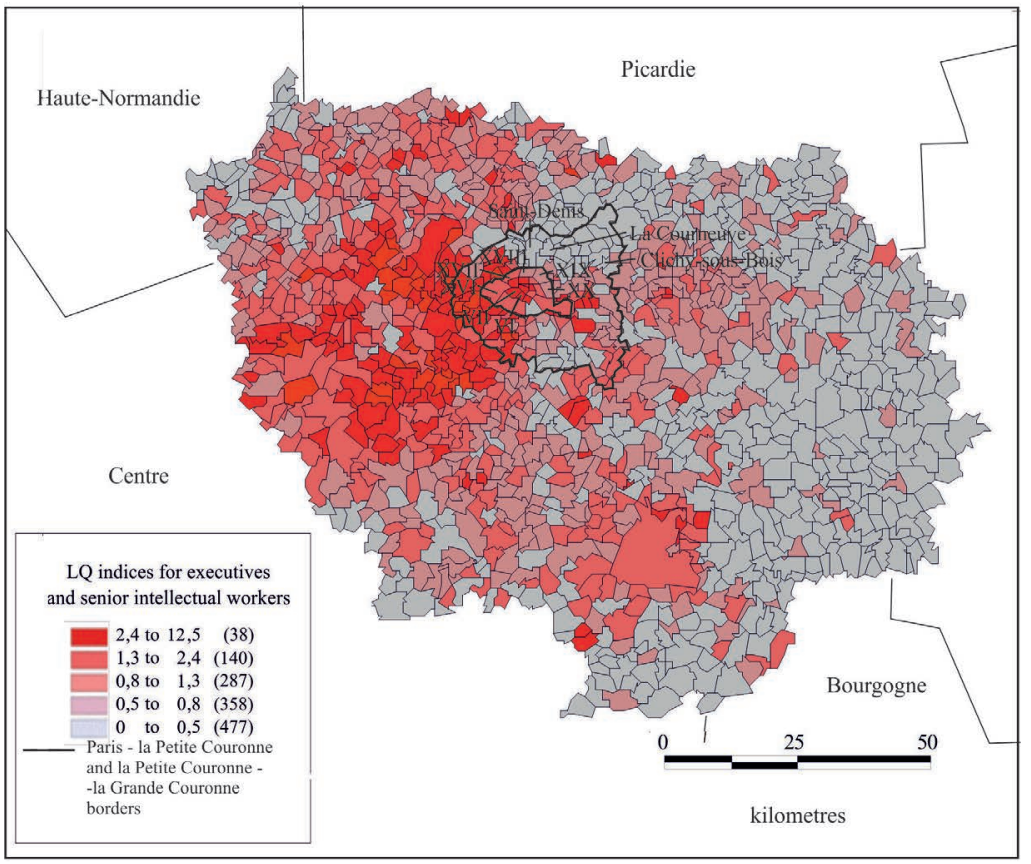

Figure 8. LQ indices for executives and senior intellectual workers 


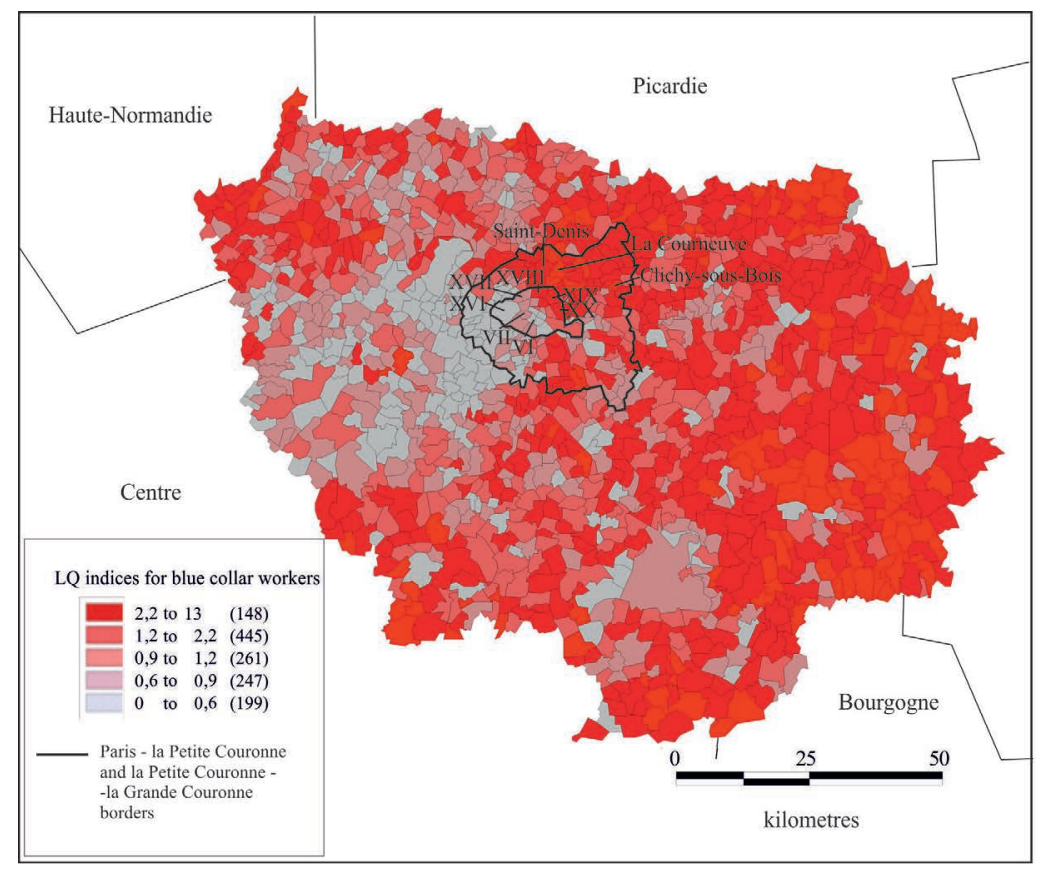

Figure 9. LQ indices for blue collar workers

index and isolation index are higher in the cities, thus indicating a more uneven distribution of their residents than is present in the wider metropolitan areas. Thus the BMA and WMA are more homogeneous, and their inhabitants belong mainly to lower-status groups The outcomes indicate a dominating role of the cities within the metropolitan areas. On the other hand, in Paris, the border between the city and its metropolitan area is not so visible.

The three basic dimensions to residential differentiation involved: socioeconomic differentiation (most visibly poor vs. rich), sociodemographic differentiation (young people vs, old people, families with children vs. other small households), and sociocultural differentiation (foreigners $v$. nationals). This is a finding in line with those of other contemporary studies. In the areas considered in this article, the most-separated groups are characterised by the most extreme social status, but while in the case of Warsaw this is mostly low social status, in the cases of Berlin and Paris - it is mostly high social status. This difference can be associated with the fact Paris, as well as to a lesser extent Berlin, is more fully linked in with the global cities system.

When segregation resulting from demographic and socio-economic features, as well as affiliation to foreigner groups, is considered, important differences within the studied areas are seen to be present. Within the PMA and Paris, as well as the WMA and Warsaw, the most pronounced segregation is that concerning socio-economic groups. In contrast, within the WMA, groups of lower social status (as measured by reference to level of education, professional group and support in the form of benefits) threatened with social exclusion, stand out, whereas within the PMA it is people of high social status (as measured by reference to level of education and affiliation to social and professional groups) that stand out.

Within the PMA and Paris high segregation indices secondarily involve foreigners, which is to say that ethnic segregation takes 
place. Interestingly, the values assumed by this index are higher for the PMA than for the city of Paris. This reflects a greater concentration of these groups beyond the city centre, given their residence in the spacious housing estates built since the 1970s, under large-scale residential building programmes for immigrants. Within the BMA and Berlin the highest segregation level again relates to ethnic issues (foreigners). However, in Germany foreigners are concentrated in the city, with only an insignificant number present in adjacent municipalities. A concentration of foreigners arises from many causes, but the most important seems connected with the city's history (given that only the western part of the capital was in the former FRG, where immigration policy was more open to foreigners; while the eastern part and entire metropolitan area were within the DDR). Local authority policy also plays a role (via support for housing construction within urban areas, the concentration of social housing in the city region, and efforts to counteract urban sprawl).

Within the BMA and Berlin, segregation indices assuming the second-highest values relate to socio-economic features. It should be underlined that in these areas it is more segregation of people of higher status than of lower status that is to be observed, albeit with differences more limited than in the studied areas in France and Poland.

The analysis of data regarding demographic features of the studied areas seems interesting. Within the PMA and BMA, demographic features constituted the third group of features indicating segregation. In the case of the WMA it was the second group (though it needs to be recalled that numbers of foreigners within the wider WMA are so small that they are not included in the statistics). Among the studied groups relatively marked segregation of the over-60s was clearly visible.

In formerly-communist cities, such as Warsaw, segregation relating to age was a key factor impacting upon the distribution of particular groups (Dangschat 1985). Currently,
Warsaw is experiencing a significant degree of concentration of older people (also frequently of lower status) in the central districts of the city. This ensures a higher concentration of young people in peripheral districts. However, it should be recalled and highlighted that the analysed indices reflect the 2002 situation, and so do not present the most recent urban processes, mostly gentrification, that are occurring in the central districts of Warsaw. However, this a fragmentary (sometimes a point) process, and one that this involves the city's downtown districts to varying extents. It is nevertheless an influential process, of which an interesting example occurring dynamically (inter alia thanks to the activation of a second underground railway line) is the right-bank Praga Północ district, until recently associated solely with the concentration of people of low social status. Wola district is also undergoing marked social changes relating to new large-scale developments involving units both residential (the so-called 19th district) and business-related. The second factor impacting upon changes redistributing people in different age groups is the extension (post-2002) of residential estates in the outskirts: among other places in Wilanów (the so-called Miasteczko Wilanów) or Białołęka.

Analysing German data, one might also assume that the eastern (former GDR) part would segregate more in relation to age and size of household than to socio-economic status and ethnic origin. However, the 2012 data make it clear that such divisions once existing have faded. Currently, Berlin has a significant concentration of older people, but also of those aged 18-30. Frequently older people live in districts outside the city centre, while the young reside in central areas. Berlin has a very clear gentrification process, especially in districts previously resided in by a significant number of foreigners, or else associated with deprivation in the communist era. According to Groyecka (2014), neighborhoods like Prenzlauer Berg, Mitte, Kreuzberg and Friedrichshain have also passed through the first stages of gentrification. However, 
this process is also beginning to reach neighbourhoods further from the centre, for example Neukölln. Previous residents are pushed outside the so-called Ring, in other words beyond the city centre, and this is impacting on change to the social and spatial structure of the city. It is also worth mentioning that the process of gentrification in Berlin (especially its eastern part) is proceeding more slowly than in other Western European capitals. Berlin has never been the economic capital of the country, and business, industry and services are located in other parts of Germany. Berlin is the home of political and cultural institutions, so an inflow of more-affluent residents and investors is important for the city authorities, and is something that may result in more-marked segregation in the future.

In the case of France, older people are not so highly concentrated in the centre of Paris, and usually live in smaller cities or even villages $-2 / 3$ of the households formed by pensioners and professionally inactive people are resident in detached houses in periurban areas (Berger et al. 2010). Within a dynamic approach being taken, rejuvenation of Paris is clearly visible. The distribution of older people is partially related to the social and professional status of the group, as the period of thirty years of post-War prosperity, the so called Trentes Glorieuses, certainly impacted upon the beginnings of their professional lives. It resulted in a concentration of representatives of this group in rich municipalities and among owners of detached houses. Currently, older people seem unwilling to leave their own houses, which can be adjusted to the needs of the elderly; and this serves as a further indicator of their social status. Therefore they prefer to live in a known local environment which at their new stage of life gains significance, and thanks to a high level of mobility, they have unlimited possibilities to move around by car (Berger et al. 2010).

The social and spatial structure of Paris, though stable, is subject to major change through gentrification, which began in the 1960 s and is progressing towards the northeastern part, through areas constituting initiating focal points and pioneering fronts, although it is actually not people of the highest status who incite the process, but rather the so-called bobo - bourgeois-bohème group (Clerval 2010). In the future we can expect further elitisation of space, with the only areas holding out against gentrification being the core parts of some of the immigrant enclaves ${ }^{11}$. Their lower attractiveness to the higher-status population may inter alia be associated with the high percentage of immigrant students at district schools (Pinçon, Pinçon-Charlot 2014). Finally, reference to the study of enclaves of wealth and poverty should take in the thesis of Pinçon and Pinçon-Charlot (2014), whereby the 'social mix' term is used in public debate mainly to indicate low-status Paris districts in which a higher-status population invests. The converse situation is then called pauperisation. In fact, the analysis of gentrification should term its outcomes, not as a 'social mix', but as increasing homogeneity, with the uppermiddle class (the moyen bourgeoisie in line with socio-economic characteristics or the bobo - bourgeois-bohème in line with features of lifestyle and values) settling in areas formerly inhabited by a lower-status population and immigrants.

The findings in this article would seem to fit well with contemporary debate on the formation of social disparities. The outcomes presented relate closely to existing theories, of which one of the most significant worth citing here would be the dual city theory. The latter seeks to describe the dichotomy reflecting urban transformations on labour markets and in the sectoral patterns to a city, as reflected in development, or crisis regarding appropriate urban spaces. In fact, the concept is capturing the desire to seek connections between certain functional development paths of the city and its parts and processes of social segregation, as well as the emergence of new or changed social behaviors and lifestyles (Mollenkopf \& Castells 1991). Closely related

${ }^{11}$ There are some exceptions to this rule, e.g. Chateau Rouge. 
to the concept of the dual city is the global city theory proposal of Sassen (1991). Apart from the functional aspects, it also relates to disparities in a city, as shaped by the process of 'circulation of capital'. Sassen talks about a 'new geography of concentration and marginalization', or 'new logic of concentration', based on neo-liberal economics, deregulation of markets and consumption.

Both of the above theoretical concepts emphasise the relationship between the universalism of globalisation and specific local conditions for the development of cities. Globalisation is responsible, not only for different networks of cities, but also for the emergence and rise of disparities within them, albeit on different spatial scales. The universalism of globalisation thus combines with local conditions, be these related to history (origins of the city, its functions, existing social and economic structures), the unique culture of inhabitants and the ensuing tendency to take individual or collective action, attachment to a city, valuation, or a sense of responsibility to the surrounding space.

For example gentrification is taking place in the cities studied to differing degrees in Paris it is in the most advanced phase; in Berlin it is less developed and not necessarily associated with the corporate class (as in global cities) but rather with a new movement of artists, students, etc.; and in Warsaw it operates pointwise and is associated with a mixture of ownership issues and the growing needs of wealthy individuals.

Not without significance in explaining differences between the studied cities is the path of development adopted by the authorities. Paris has always been perceived as a cultural centre, as a very elite place in which to live. In turn, Berlin seems to be struggling more, to catch up from economic backwardness and compete with West German cities, and thus to become a strong capital. Warsaw is also trying to overcome underdevelopment and to become a regional centre. Acceptance of different developmental paths can be affected by the fact that different social groups are encouraged to come and settle in a given city and social structure, as well as given the way the scale of segregation in such a situation changes.

Varied historical and institutional contexts have resulted in different social and spatial structures (as presented above), though increasing elitisation of cities seems to be a common feature. This process is most advanced in Paris, is dynamic in Berlin and is occurring pointwise in Warsaw. The elitisation of metropolitan areas and cities is related to structural changes in post-modern societies, but also to contemporary processes typical for neoliberal cities, such as gentrification, the presence of closed residential estates, intensified residential segregation, and the exclusion of marginalised groups. These processes overlap with socio-spatial structures inherited from the past, and multidimensional analysis of segregation allows the complexity of current changes to be accounted for, with interrelated demographic, social and ethnic dimensions being shaped in a variety of ways, if all leading to the elitisation of urban areas, as combined with the exclusion of certain enclaves of poverty.

\section{Acknowledgments}

This project is financed by the National Science Centre in Poland (funds granted on the basis of decision number DEC-2013/09/B/ HS4/01492).

Editors' note:

Unless otherwise stated, the sources of tables and figures are the authors', on the basis of their own research. 


\section{References}

Berent M., 2007. Partnerships for demolition: The governance of urban renewal in East. Germany's shrinking cities. International Journal of Urban and Regional Research, vol. 3, no. 33, pp. 754-769.

Berger M., Rougé L., Thomann S., Thouzellier C., 2010. Vieillir en pavillon: Mobilités et ancrages des personnes âgées dans les espaces périurbains d'aires métropolitaines (Toulouse, Paris, Marseille). Espaces populations sociétés, 2010(1), pp. 1-15, http://www.revues.org [25 January 2015].

Bidoux P.E., VIROT P., 2011. L'accèss à l'emploi et au logement s'amélior pour les immigrés à Paris mais les inégalités et les discriminations persistent. À la page. INSEE. Ile-De-France. APUR, no. 376.

Clerval A., 2010. Les dynamiques spatial de la gentrification à Paris. Cybergeo: European Journal of Geography, Espace, Société, Territoire, document 505, http://cybergeo.revues.org [25 January 2015].

DangsChat J., 1985. Résidentielle segregation der Altersgruppen in Warschau. Geografische Zeitschrift, vol. 73, no. 2, pp. 81-105.

Duncan O.D., Duncan B., 1955. A methodological analysis of segregation indexes. American Sociological Review, vol. 20, no. 2, pp. 210-217.

FriedrisChS J., TRIemer S., 2008. Gespaltene Städte?: soziale und ethnische Segregation in deutschen Großstädten. Wiesbaden: VS Verlag für Sozialwissenschaften.

FuıITA K., 2012. Conclusion: Residential segregation and urban theory [in:] T. Maloutas, K. Fujita (eds.), Residential segregation in comparative perspective: Making sense of contextual diversity, Farnham: Ashgate, pp. 285-322.

GĄDECKI J., 2009. Za murami. Osiedla grodzone w Polsce - analiza dyskursu. Wrocław: Wydawnictwo Uniwersytetu Wrocławskiego.

Gasior-NiemieC A., 2007. Grodzenie miast: Casus Warszawy. Studia Regionalne i Lokalne, no. 4(30), pp.5-30.

GóRCZYŃSKA M., 2014. Unique or universal? Mechanisms and processes of social change in post-socialist Warsaw. Hungarian Geographical Bulletin, vol. 63, no. 3, pp. 255-270.
GroyeCKA D., 2014. Gentryfikacja Berlina. Od życia na podsłuchu do kultury caffe latte. Gdańsk: Wydawnictwo Naukowe Katedra.

GrZegorczyK A., 2013. Social and ethnic segregation in the Paris metropolitan area at the beginning of the 21st century. Miscellanea Geographica, vol. 17, no. 2, pp. 20-29.

GrzegorczYk A., 2014. The Paris suburbs - blessed or cursed? [in:] M. Czerny, G. Hoyos Castillo (eds.), Suburbanization versus peripheral sustainability of rural-urban areas fringes. Urban Development and Infrastructure Series, New York: Nova Publishers, pp. 89-102.

GrZegorczyK A., JacZewSKA B., 2015. Measures of social segregation in the context of Warsaw, Berlin and Paris metropolitan areas. Miscellanea Geographica, vol. 19, no. 3, pp. 22-35.

Hamnett C., 1994. Social polarisation in global cities: Theory and evidence. Urban Studies vol. 31, no. 3, pp. 401-424.

Häussermann H., Kapphan A., 2002. Berlin: Von der geteilten zur gespaltenen Stadt?: Sozialräumlicher Wandel seit 1990. Wiesbaden: VS Verlag für Sozialwissenschaften.

INSEE, 2014. National Institute of Statistics and Economic Studies. http://www.insee.fr [24 July 2014].

JAŁOWIECKI B., 2000. Społeczna przestrzeń metropolii. Warszawa: Scholar.

Kaufman J.L., 2011. Chicago: Segregation and new urban poverty [in:] S. Musterd, W. Ostendorf (eds.), Urban segregation and the welfare state: Inequality and exclusion in western cities, London-New York: Routledge, pp. 45-63.

KeMPER F.J., 1998a. Residential segregation and housing in Berlin: Changes since unification. GeoJournal, vol. 46, no. 1, pp. 17-28.

KEMPER F.J., 1998b. Restructuring of housing and ethnic segregation: Recent developments in Berlin. Urban Studies, vol. 35, no. 10, pp. 1765-1789.

Kovács Z., 2013. Residential segregation in Budapest before and after transition. T. Maloutas, K. Fujita (eds.), Residential segregation in comparative perspective: Making sense of contextual diversity, Farnham: Ashgate, pp. 197-216.

LAJOIE G., 1998. La ségrégation des populations urbaines de 1982 à 1990. Pumain, F. Godard, A. Chenu (eds.), Données urbaines, Paris: Anthropos, pp. 191-206. 
MaloutAS T., 2012. Introduction: Residential segregation in context [in:] T. Maloutas, K. Fujita (eds.), Residential segregation in comparative perspective: Making sense of contextual diversity, Farnham: Ashgate, pp. 1-37.

Maloutas T., Fujita K. (eds.), 2012. Residential segregation in comparative perspective: Making sense of contextual diversity. Farnham: Ashgate.

MarcińcZAK S., 2013. Segregacja społeczna w mieście postsocjalistycznym. Bukareszt, Warszawa i Talin na początku XXI wieku. Łódź: Wydawnictwo Uniwersytetu Łódzkiego.

Marcuse P., Van Kempen R., 2000. Globalizing cities: A new spatial order? Oxford: Wiley-Blackwell.

MASSEY D.S., Denton N.A., 1988. The dimensions of residential segregation. Social Forces, vol. 67, no. 2, pp. 281-315.

Maurin É., 2004. Le ghetto français. Enquête sur le séparatisme social. La République des Idées. Paris: Le Seuil.

MBPRW, 2014. Delimitacja obszaru metropolitalnego Warszawy. Mazowieckie Biuro Planowania Regionalnego w Warszawie, http://www. mbpr.pl [24 June 2014].

MerRy M., 2013. Equality, citizenship, and segregation: A defense of separation. New York: Palgrave Macmillan.

MitCHELL K., 2011. Marseille's not for burning: Comparative networks of integration and exclusion in two french cities. Annals of the Association of American Geographers, vol. 101, no. 2, pp. 404-423.

Mollenkopf J.H., Castells M., 1991. Dual city: Restructuring New York, New York: Sage.

Monitoring Soziale Stadtentwicklung, 2013. Berlin: Senatsverwaltung für Stadtentwicklung und Umwelt, http://www.stadtentwicklung.berlin.de/planen/basisdaten_stadtentwicklung/ monitoring/ [24 February 2016].

Musterd S., Ostendorf W., 2011. Urban segregation and the welfare state: Inequality and exclusion in western cities. London-New York: Routledge.

Musterd S., van Gent W., 2012. Residential location and housing moves of immigrants and natives in the Amsterdam metropolitan context [in:] N. Finnley, G. Catney (eds.), Minority internal migration in Europe, International
Population Studies, Farnham, Surrey: Ashgate, pp. 89-110.

Musterd S., van Gent W., 2016. Changing welfare context and income segregation in Amsterdam and its metropolitan area, 2004-2011 [in:] T. Tammaru, S. Marcińczak, M. Van Ham, S. Musterd (eds.), Socio-economic segregation in European Capital Cities: East meets West, London: Routledge, pp. 55-79.

PAN Ké SHON J.L. 2011. La ségrégation des immigrés en France: état des lieux. Population - Sociétés, 477, http://www.insee.fr. [1 May 2012].

Park E., Burgess E., McKenzie R., 1925. The City: Suggestions for investigation of human behavior in the urban environment. Chicago: University of Chicago Press.

Pinçon M., Pinçon-Charlot M., 2007. Les ghettos du gotha. Au cœur de la grande bourgeoisie. Paris: Éditions Points.

Pinçon M., Pinçon-Charlot M., 2014. Sociologie de Paris. Paris: Éditions La Découverte.

PolanSKA D.V., 2011. The emergence of enclaves of wealth and poverty: A sociological study of residential differentiation in post-communist Poland. Acta Universitatis Stockholmiensis. Stockholm Studies in Sociology, 50, Stockholm: Department of Sociology. Stockholm University.

Préteceille E., 2000. Segregation, class and politics in large cities [in:] A. Bagnsco A., P. Le Galès (eds.), Cities in contemporary Europe, Cambridge: Cambridge University Press, pp. 74-97.

Préteceille E., 2006. La ségrégation sociale a-telle augmenté? La métropole parisienne entre polarisation et mixité. Sociétés contemporaines, 2006/2, no. 62, pp. 69-93, http://www.cairn. info/revue-societes-contemporaines-2006-2page-69.htm [24 June 2015].

PréteCeille E., 2012. Segregation, social mix and public policies in Paris [in:] T. Maloutas, K. Fujita (eds.), Residential segregation in comparative perspective: Making sense of contextual diversity, Farnham: Ashgate, pp. 153-176.

RheIN C., 1998. The working class, minorities and housing in Paris, the rise of fragmentation. GeoJournal, vol. 46, no. 1, pp. 51-62.

SadAhIRO Y., Hong S., 2013. Decomposition approach to the measurement of spatial segregation. CSIS Discussion Paper, no. 119R, http://www. csis.u-tokyo.ac.jp/dp/119r1.pdf [1 July 2015]. 
SAFI M., 2009. La dimension spatial de l'intégration : évolution de la ségrégation des population immigrées en France entre 1968 et 1999. Revue française de sociologie, vol. 50, no. 3, pp. 521552, http://www.cairn.info/revue-francaise-desociologie-2009-3-page-521.htm [1 June 2012].

SASSEN S., 1991. The global city: New York, London, Tokyo. Princeton: Princeton University.

SŁOMCZYŃSKI K.M., 1989. Social structure and mobility: Poland, Japan and the United States. Warszawa: Instytut Filozofii i Socjologii PAN.

SMĘTKOWSKI M., 2009. Zróżnicowanie społeczno-przestrzenne Warszawy - inercja czy metamorfoza struktury miasta? Przegląd geograficzny, vol. 81, no. 4, pp. 461-481.

Statistical Office in Warsaw, 2014. http://warszawa.stat.gov.pl/ [1 July 2014].

Statistisches Bundesamt, 2014. https://www. destatis.de/DE/Startseite.html [1 July 2014].

Stępniak M., WęcŁawowicz G., Górczyńska M., BierzYŃSKI A., 2009. Warszawa w świetle narodowego spisu powszechnego 2002. Atlas Warszawy, 11, Warszawa: Instytut Geografii i Przestrzennego Zagospodarowania PAN.

SÝKORA L., 1999. Processes of socio-spatial differentiation in post-communist Prague. Housing Studies, vol. 14, no. 5, pp. 679-701.

Tammaru T., Musterd S., van Ham M., MARCIŃCZAK S., 2016. A multi-factor approach to understanding socio-economic segregation in European capital cities [in:] T. Tammaru, S. Marcińczak, M. van Ham, S. Musterd (eds.), Socio-economic segregation in European Capital Cities: East meets West, London: Routledge, pp. 1-29.

van Kempen R., Murie A., 2009. The new divided city: Changing patterns in European Cities. Tijdschrift voor Economische en Sociale Geografie, vol. 100, no. 4, pp. 377-398.
WarZYWODA-KRUSZYŃSKA W., 2011. Badania nad ekologiq i dziedziczeniem biedy w wielkim mieście. Warszawa: Instytut Socjologii Uniwersytetu Warszawskiego, Wydawnictwo Instytut Filozofii i Socjologii PAN.

WECŁAWOWICZ G., 1979. The structure of socioeconomic space in Warsaw in 1931 and 1970: A study in factorial ecology [in:] R.A. Franch, F.E. Hamilton (eds.), The socialist city: Spatial structure and urban policy, Chichester-New York: John Willey \& Sons, pp. 387-424.

WęctaWOWICZ G., 1998. Social polarisation in postsocialist cities: Budapest, Prague and Warsaw [in:] G. Enyedi (ed.), Social change and urban restructuring in Central Europe, Budapest: Akademiai Kiadó, pp. 55-66.

WĘCŁAWOWICZ G., 2004. Where the grass is greener in Poland: Regional and intra-urban inequalities [in:] R. Lee, D.M. Smith, (eds.), Geographies and moralities: International perspectives on development, justice and place, London: Blackwell, pp. 62-77.

WęCLAWOWICZ G., 2008. Ludność z wyksztatceniem wyższym $w$ strukturze społeczno-przestrzennej Warszawy [in:] Warszawa Akademicka. Warszawa: Instytut Problemów Współczesnej Cywilizacji, pp. 21-29.

White M.J., 1983. The measurement of spatial segregation. American Journal of Sociology, vol. 88, no. 5, pp. 1008-1018.

White P., 2011. Ideologies, social segregation in Paris [in:] S. Musterd, W. Ostendorf (eds.), Urban segregation and the welfare state: Inequality and exclusion in western cities, London-New York: Routledge, pp. 148-167.

Wong D., 2003. Spatial decomposition of segregation indices: A framework toward measuring segregation at multiple levels. Geographical Analysis, vol. 35, no. 3, 179-194. 


\section{Annex 1}

Formulae used in this article:

Dissimilarity index $(D)$

$$
\begin{aligned}
& D=1 / 2 \sum_{i=1}^{n}\left|\frac{X_{i}}{X}-\frac{y_{i}}{Y}\right| \\
& D \in\langle 0,1\rangle
\end{aligned}
$$

where $x_{i}$ and $y_{i}$ are the numbers of members in the analyzed groups in are unit $i$, and $X$ and $Y$ the groups' population sizes in the whole city, as subdivided into $n$ area units

$$
\begin{aligned}
& \text { Isolation index }\left({ }_{x} P_{x}\right) \\
& { }_{x} P_{x}=\sum_{i=1}^{n}\left(\frac{x_{i}}{x} \times \frac{x_{i}}{t_{i}}\right) \\
& P \in\langle 0,1\rangle
\end{aligned}
$$

where $t_{i}$ is the total population in are unit $i$

Delta index (DEL)

$$
\begin{aligned}
& D E L=1 / 2 \sum_{i=1}^{n}\left|\frac{x_{i}}{X}-\frac{a_{i}}{A}\right| \\
& D E L \in\langle 0,1\rangle
\end{aligned}
$$

where $a_{\mathrm{i}}$ is the land area of are unit $i$, and $A$ the total land area in the city

$$
\begin{aligned}
& \text { Absolute centralization index (ACE) } \\
& \begin{array}{l}
A C E=\left[\sum_{i=1}^{n}\left(X_{i-1} \times A_{i}\right)\right]-\left[\sum_{i=1}^{n}\left(X_{i} \times A_{i-1}\right)\right] \\
A C E \in\langle-1,1\rangle
\end{array}
\end{aligned}
$$

where $X_{i}$ and $Y i$ are the respective cumulative proportions of $X^{\prime}$ 's and $Y^{\prime}$ 's population in the tract

Spatial proximity index (SP)

$$
\begin{aligned}
P_{x x} & =\sum_{i=1}^{n} \sum_{j=1}^{n} \frac{x_{i} x_{j} c_{i j}}{X^{2}} \quad P_{x y}=\sum_{i=1}^{n} \sum_{j=1}^{n} \frac{x_{i} y_{j} c_{i j}}{X Y} \\
S P & =\frac{X P_{x x}+Y P_{y y}}{T P_{t t}} \\
S P & >0
\end{aligned}
$$

where $x_{i}$ is population size in area unit $i, x_{i}$ the population in are unit $j, c_{i j}$ the distance function between areas, $P_{x x}$ the average proximity between group $X$ members, $P_{x y}$ the average proximity between members of $X$ and $Y, P_{y y}$ the average proximity between group $Y$ members, and $P_{t t}$ the average proximity among all members of the population

$$
\begin{aligned}
& \text { Modified location index } L Q_{p} \\
& L Q_{p}=\frac{{ }_{k} x_{i} / y_{i}{ }^{\prime}}{{ }_{k} X / Y^{\prime}} \\
& L Q_{p} \geq 0
\end{aligned}
$$

where ${ }_{k} x_{i}$ is the population size in group $k$ and in area unit $i, y_{i}^{\prime}$ population size in area unit $i$, as decreased by the $k$ group population, $X$ the population in the $k$ group in the whole city, $Y^{\prime}$ the city population size reduced by the $k$ group population in the city 


\section{Annex 2}

Table 1. Segregation indices in WMA and in Warsaw in 2002

\begin{tabular}{|c|c|c|c|c|c|c|c|c|c|}
\hline \multirow[b]{2}{*}{ Indicators } & \multicolumn{4}{|c|}{ Warsaw Metropolitan Area } & \multicolumn{5}{|c|}{ Warsaw } \\
\hline & 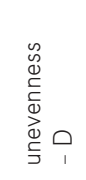 & 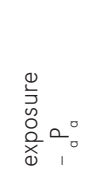 & 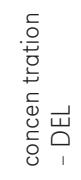 & 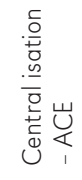 & 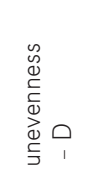 & $\begin{array}{l}0 \\
\frac{0}{3} \\
0 \\
0 \\
0 \\
0 \\
\frac{0}{x} 0^{\circ} \\
0 \\
0\end{array}$ & 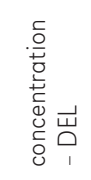 & 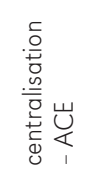 & 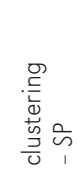 \\
\hline \multicolumn{10}{|l|}{ Age } \\
\hline $0-14$ & 0.098 & 0.152 & 0.556 & 0.560 & 0.063 & 0.127 & 0.340 & 0.386 & 0.997 \\
\hline $15-29$ & 0.009 & 0.236 & 0.625 & 0.640 & 0.044 & 0.243 & 0.379 & 0.420 & 0.998 \\
\hline $30-44$ & 0.024 & 0.198 & 0.613 & 0.632 & 0.031 & 0.195 & 0.373 & 0.428 & 0.996 \\
\hline $45-59$ & 0.035 & 0.217 & 0.649 & 0.669 & 0.053 & 0.234 & 0.389 & 0.423 & 0.999 \\
\hline 60 and older & 0.066 & 0.196 & 0.657 & 0.682 & 0,124 & 0.235 & 0.476 & 0.530 & 1,004 \\
\hline \multicolumn{10}{|c|}{ Family and household size in separate apartments } \\
\hline With one child & 0.060 & 0.555 & 0.588 & 0.669 & 0.020 & 0.606 & 0.374 & 0.412 & 1.003 \\
\hline With two children & 0.035 & 0.360 & 0.510 & 0.592 & 0.022 & 0.336 & 0.337 & 0.366 & 0.998 \\
\hline With three children or more & 0.214 & 0.128 & 0.381 & 0.397 & 0.084 & 0.064 & 0.298 & 0.328 & 0.992 \\
\hline 1 person & 0.100 & 0.276 & 0.735 & 0.753 & 0.105 & 0.330 & 0.481 & 0.574 & 1.008 \\
\hline 2 people & 0.048 & 0.262 & 0.702 & 0.724 & 0.037 & 0.285 & 0.436 & 0.512 & 0.999 \\
\hline 3 people & 0.020 & 0.208 & 0.677 & 0.694 & 0.077 & 0.216 & 0.383 & 0.425 & 1.001 \\
\hline 4 people & 0.097 & 0.180 & 0.616 & 0.626 & 0.130 & 0.163 & 0.348 & 0.367 & 1.003 \\
\hline 5 people and more & 0.262 & 0.117 & 0.472 & 0.465 & 0.153 & 0.056 & 0.315 & 0.341 & 0.998 \\
\hline \multicolumn{10}{|l|}{ Education } \\
\hline Higher education & 0.186 & 0.776 & 0.754 & 0.821 & 0.086 & 0.735 & 0.388 & 0.440 & 0.998 \\
\hline Post-secondary school & 0.092 & 0.949 & 0.702 & 0.624 & 0.019 & 0.945 & 0.391 & 0.440 & 1.000 \\
\hline Upper secondary school & 0.066 & 0.622 & 0.684 & 0.728 & 0.016 & 0.593 & 0.400 & 0.456 & 0.995 \\
\hline Basic vocational school & 0.178 & 0.821 & 0.493 & 0.468 & 0.110 & 0.887 & 0.406 & 0.439 & 0.995 \\
\hline Primary school & 0.138 & 0.756 & 0.513 & 0.536 & 0.066 & 0.829 & 0.391 & 0.440 & 0.994 \\
\hline $\begin{array}{l}\text { Primary school unfinished } \\
\text { or no education }\end{array}$ & 0.248 & 0.958 & 0.400 & 0.378 & 0.077 & 0.986 & 0.353 & 0.402 & 0.993 \\
\hline \multicolumn{10}{|l|}{ Profession } \\
\hline $\begin{array}{l}\text { Legislators, senior officials } \\
\text { and managers }\end{array}$ & & & & & 0.152 & 0.143 & 0.385 & 0.310 & 1.000 \\
\hline Specialists & & & & & 0.160 & 0.285 & 0.405 & 0.435 & 0.999 \\
\hline $\begin{array}{l}\text { Technicians and associate } \\
\text { professionals }\end{array}$ & & & & & 0.051 & 0.205 & 0.404 & 0.389 & 0.996 \\
\hline Office workers & & & & & 0.046 & 0.124 & 0.415 & 0.408 & 0.994 \\
\hline $\begin{array}{l}\text { Personal services workers } \\
\text { and retailers }\end{array}$ & & & & & 0.072 & 0.108 & 0.407 & 0.395 & 0.994 \\
\hline $\begin{array}{l}\text { Farmers, gardeners, forest- } \\
\text { ers and fishermen }\end{array}$ & & & & & 0.706 & 0.132 & 0.801 & 0.148 & 1.006 \\
\hline $\begin{array}{l}\text { Industrial workers and } \\
\text { craftsmen }\end{array}$ & & & & & 0.181 & 0.091 & 0.422 & 0.431 & 0.996 \\
\hline
\end{tabular}




\begin{tabular}{|c|c|c|c|c|c|c|c|c|c|}
\hline \multirow[b]{2}{*}{ Indicators } & \multicolumn{4}{|c|}{ Warsaw Metropolitan Area } & \multicolumn{5}{|c|}{ Warsaw } \\
\hline & 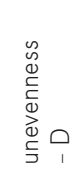 & 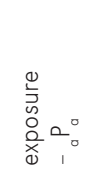 & 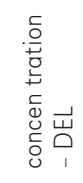 & 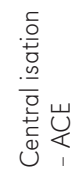 & 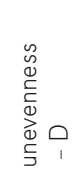 & 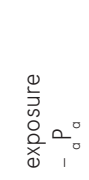 & 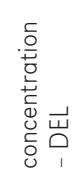 & 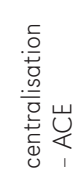 & 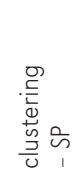 \\
\hline \multicolumn{10}{|l|}{ Profession } \\
\hline $\begin{array}{l}\text { Operators and installers } \\
\text { of machinery and equip- } \\
\text { ment }\end{array}$ & & & & & 0.172 & 0.054 & 0.404 & 0.427 & 0.994 \\
\hline $\begin{array}{l}\text { Elementary } \\
\text { occupations }\end{array}$ & & & & & 0.075 & 0.057 & 0.431 & 0.437 & 0.992 \\
\hline \multicolumn{10}{|l|}{ Unemployment } \\
\hline Unemployed & 0.066 & 0.149 & 0.598 & 0.600 & 0.055 & 0.138 & 0.398 & 0.446 & 0.994 \\
\hline \multicolumn{10}{|l|}{ Social benefits } \\
\hline Benefits in total & 0.041 & 0.301 & 0.555 & 0.611 & 0.079 & 0.295 & 0.448 & 0.516 & 1.002 \\
\hline Pension & 0.051 & 0.176 & 0.591 & 0.662 & 0.106 & 0.193 & 0.464 & 0.532 & 1.000 \\
\hline Disability pension in total & 0.102 & 0.085 & 0.528 & 0.529 & 0.056 & 0.068 & 0.431 & 0.492 & 0.995 \\
\hline Disability pension & & & & & 0.048 & 0.042 & 0.425 & 0.476 & 0.994 \\
\hline Unemployment benefits & 0.134 & 0.051 & 0.502 & 0.529 & 0.099 & 0.007 & 0.414 & 0.445 & 0.994 \\
\hline Social support & & & & & 0.177 & 0.006 & 0.472 & 0.546 & 0.994 \\
\hline Other unearned & & & & & 0.053 & 0.026 & 0.419 & 0.481 & 0.994 \\
\hline \multicolumn{10}{|l|}{ Disability } \\
\hline Disabled people in total & 0.428 & 0.098 & 0.407 & 0.320 & 0.076 & 0.111 & 0.440 & 0.511 & 0.996 \\
\hline Legally & 0.431 & 0.076 & 0.414 & 0.297 & 0.068 & 0.082 & 0.439 & 0.507 & 0.995 \\
\hline Only biologically & 0.421 & 0.024 & 0.390 & 0.397 & 0.111 & 0.030 & 0.452 & 0.525 & 0.995 \\
\hline
\end{tabular}


Table 2. Segregation indices in BMA and in Berlin in 2012

\begin{tabular}{|c|c|c|c|c|c|c|c|c|c|}
\hline & \multicolumn{4}{|c|}{ Berlin Metropolitan Area } & \multicolumn{5}{|c|}{ Berlin } \\
\hline & 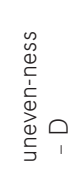 & 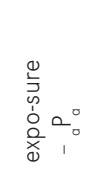 & 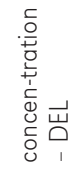 & 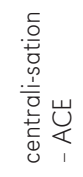 & 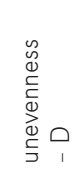 & 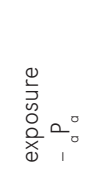 & 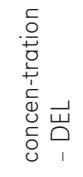 & 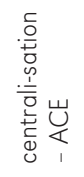 & iे \\
\hline \multicolumn{10}{|l|}{ Age } \\
\hline Under 18 & 0.030 & 0.145 & 0.603 & 0.634 & 0.029 & 0.151 & 0.215 & 0.239 & 1.112 \\
\hline 18 up to under 30 & 0.070 & 0.150 & 0.657 & 0.652 & 0.086 & 0.169 & 0.278 & 0.289 & 1.066 \\
\hline 30 up to under 50 & 0.021 & 0.296 & 0.601 & 0.626 & 0.055 & 0.311 & 0.247 & 0.261 & 1.083 \\
\hline 50 up to under 65 & 0.050 & 0.209 & 0.539 & 0.547 & 0.068 & 0.194 & 0.228 & 0.184 & 1.143 \\
\hline 65 and older & 0.041 & 0.209 & 0.552 & 0.545 & 0.100 & 0.203 & 0.172 & 0.140 & 1.178 \\
\hline \multicolumn{10}{|l|}{ Household size } \\
\hline One-person & 0.084 & 0.494 & 0.710 & 0.701 & 0.046 & 0.549 & 0.268 & 0.262 & 1.014 \\
\hline Two-person & 0.075 & 0.338 & 0.562 & 0.566 & 0.075 & 0.297 & 0.200 & 0.172 & 1.181 \\
\hline Three-person & 0.333 & 0.118 & 0.528 & 0.558 & 0.054 & 0.094 & 0.228 & 0.212 & 1.158 \\
\hline Four-person and more & 0.163 & 0.085 & 0.607 & 0.696 & 0.077 & 0.078 & 0.233 & 0.265 & 1.145 \\
\hline \multicolumn{10}{|c|}{ Household average monthly income } \\
\hline Under 900 & 0.068 & 0.172 & 0.693 & 0.658 & 0.092 & 0.191 & 0.303 & 0.314 & 1.082 \\
\hline 900 up to under 1,300 & 0.018 & 0.175 & 0.632 & 0.622 & 0.046 & 0.177 & 0.244 & 0.238 & 1.133 \\
\hline 1,300 up to under 1,500 & 0.074 & 0.083 & 0.664 & 0.692 & 0.035 & 0.083 & 0.228 & 0.206 & 1.163 \\
\hline 1,500 up to under 2,000 & 0.031 & 0.174 & 0.641 & 0.634 & 0.028 & 0.177 & 0.222 & 0.229 & 1.126 \\
\hline 2,000 up to under 2,600 & 0.028 & 0.151 & 0.617 & 0.627 & 0.039 & 0.149 & 0.208 & 0.203 & 1.139 \\
\hline 2,600 and more & 0.057 & 0.255 & 0.599 & 0.654 & 0.089 & 0.247 & 0.203 & 0.192 & 1.182 \\
\hline \multicolumn{10}{|l|}{ Education } \\
\hline Polytechnic/ university & 0.122 & 0.313 & 0.715 & 0.732 & 0.118 & 0.372 & 0.286 & 0.259 & 1.020 \\
\hline $\begin{array}{l}\text { Secondary school (high } \\
\text { school) or equivalent degree }\end{array}$ & 0.083 & 0.161 & 0.657 & 0.693 & 0.127 & 0.190 & 0.201 & 0.193 & 1.210 \\
\hline $\begin{array}{l}\text { Main (elementary) school } \\
\text { graduation }\end{array}$ & 0.056 & 0.181 & 0.614 & 0.610 & 0.106 & 0.201 & 0.225 & 0.215 & 1.160 \\
\hline Without school diploma & 0.050 & 0.184 & 0.635 & 0.665 & 0.092 & 0.207 & 0.266 & 0.299 & 1.090 \\
\hline \multicolumn{10}{|l|}{ Employment } \\
\hline Working population & 0.017 & 0.477 & 0.595 & 0.619 & 0.040 & 0.477 & 0.246 & 0.240 & \\
\hline Self-employed & 0.095 & 0.075 & 0.712 & 0.782 & 0.114 & 0.187 & 0.323 & 0.277 & 1.158 \\
\hline Employees & 0.039 & 0.289 & 0.631 & 0.660 & 0.012 & 0.634 & 0.244 & 0.237 & 0.845 \\
\hline Workers & 0.208 & 0.099 & 0.401 & 0.376 & 0.156 & 0.131 & 0.262 & 0.224 & 1.081 \\
\hline \multicolumn{10}{|l|}{ Profession } \\
\hline Manufacturing & 0.116 & 0.096 & 0.474 & 0.486 & 0.089 & 0.074 & 0.219 & 0.207 & 1.140 \\
\hline $\begin{array}{l}\text { Trade, hospitality industry } \\
\text { and transport }\end{array}$ & 0.034 & 0.133 & 0.613 & 0.640 & 0.064 & 0.139 & 0.265 & 0.255 & 1.122 \\
\hline Other services & 0.044 & 0.255 & 0.637 & 0.667 & 0.057 & 0.270 & 0.252 & 0.242 & 1.109 \\
\hline \multicolumn{10}{|l|}{ Unemployment } \\
\hline Unemployment & 0.061 & 0.059 & 0.630 & 0.601 & 0.106 & 0.069 & 0.297 & 0.308 & 1.157 \\
\hline \multicolumn{10}{|l|}{ Unearned resources } \\
\hline $\begin{array}{l}\text { Continuous subsistence } \\
\text { payments } \\
\text { (chapter } 3 \text { of SGB XII^) }\end{array}$ & 0.106 & 0.005 & 0.688 & 0.682 & 0.138 & 0.007 & 0.303 & 0.230 & 1.142 \\
\hline
\end{tabular}




\begin{tabular}{|c|c|c|c|c|c|c|c|c|c|}
\hline & \multicolumn{4}{|c|}{ Berlin Metropolitan Area } & \multicolumn{5}{|c|}{ Berlin } \\
\hline & 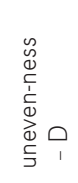 & 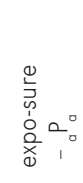 & 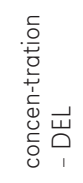 & 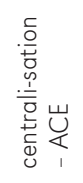 & 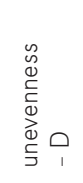 & 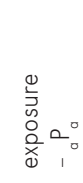 & 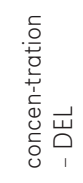 & 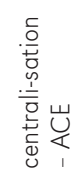 & is \\
\hline \multicolumn{10}{|l|}{ Unearned resources } \\
\hline $\begin{array}{l}\text { Basic security in old age } \\
\text { and in cases of reduced } \\
\text { earning capacity } \\
\text { (chapter } 4 \text { of SGB XII*) }\end{array}$ & 0.169 & 0.017 & 0.752 & 0.744 & 0.118 & 0.020 & 0.335 & 0.312 & 1.136 \\
\hline $\begin{array}{l}\text { Recipients of benefits } \\
\text { pursuant to chapters } 5 \text { to } 9 \\
\text { of SGB XII* }\end{array}$ & 0.071 & 0.016 & 0.644 & 0.622 & 0.093 & 0.018 & 0.291 & 0.257 & 1.140 \\
\hline \multicolumn{10}{|l|}{ Foreigners } \\
\hline Foreigners & 0.589 & 0.131 & 0.875 & 0.876 & 0.449 & 0.182 & 0.429 & 0.418 & 1.019 \\
\hline
\end{tabular}

* - SGB XII - Sozialgesetzbuch (SGB) Zwölftes Buch (XII) - Twelth Book of the Code of Social Law 
Table 3. Segregation indices in PMA and in Paris in 2011

\begin{tabular}{|c|c|c|c|c|c|c|c|c|}
\hline \multirow[b]{2}{*}{ Indicators } & \multicolumn{3}{|c|}{ Île-de-France } & \multicolumn{5}{|c|}{ Paris } \\
\hline & 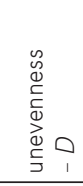 & $\begin{array}{l}0 \\
\stackrel{0}{3} \\
0 \\
0 \\
0 \\
0 \\
0\end{array}$ & 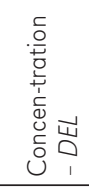 & 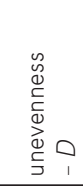 & 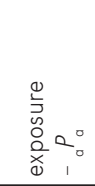 & 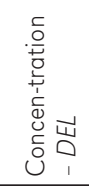 & 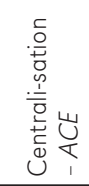 & 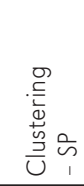 \\
\hline \multicolumn{9}{|l|}{ Age } \\
\hline $0-14$ & 0.068 & 0.255 & 0.687 & 0.050 & 0.171 & 0.232 & 0.008 & 1.001 \\
\hline $15-29$ & 0.054 & 0.267 & 0.715 & 0.033 & 0.313 & 0.225 & 0.089 & 1.001 \\
\hline $30-44$ & 0.037 & 0.289 & 0.702 & 0.051 & 0.315 & 0.243 & 0.055 & 1.003 \\
\hline $45-59$ & 0.035 & 0.243 & 0.678 & 0.022 & 0.224 & 0.211 & 0.047 & 1.000 \\
\hline 60 and older & 0,079 & 0,237 & 0,689 & 0,064 & 0,265 & 0,180 & 0,088 & 1,004 \\
\hline \multicolumn{9}{|l|}{ Family size } \\
\hline Couple with one child & 0.045 & 0.435 & 0.670 & 0.028 & 0.561 & 0.210 & 0.082 & 1.001 \\
\hline Single-parent family & 0.095 & 0.129 & 0.730 & 0.075 & 0.205 & 0.257 & 0.055 & 1.002 \\
\hline Couple without children & 0.071 & 0.304 & 0.673 & & 0.294 & & & \\
\hline Family with one child & 0.036 & 0.188 & 0.694 & 0.030 & 0.200 & 0.230 & 0.080 & 1.001 \\
\hline Family with two children & 0.049 & 0.166 & 0.668 & 0.024 & 0.066 & 0.215 & 0.081 & 1.000 \\
\hline Family with three children & 0.100 & 0.061 & 0.686 & 0.073 & 0.026 & 0.207 & 0.062 & 1.001 \\
\hline $\begin{array}{l}\text { Family with four children } \\
\text { or more }\end{array}$ & 0.208 & 0.027 & 0.732 & 0.151 & 0.030 & 0.286 & 0.026 & 1.002 \\
\hline \multicolumn{9}{|l|}{ Education } \\
\hline Long higher education & 0.270 & 0.443 & 0.760 & 0.095 & 0.724 & 0.198 & 0.148 & 1.014 \\
\hline Short higher education & 0.078 & 0.147 & 0.687 & 0.026 & 0.137 & 0.224 & 0.059 & 1.000 \\
\hline $\begin{array}{l}\text { Upper secondary school } \\
\text { (baccalaureat. Bp - brevet } \\
\text { professionnelle) }\end{array}$ & 0.040 & 0.195 & 0.689 & 0.022 & 0.181 & 0.209 & 0.049 & 1.000 \\
\hline $\begin{array}{l}\text { Basic vocational school (cap- } \\
\text { certificat d'aptitude profes- } \\
\text { sionnelle. Bep - brevet } \\
\text { d'etudes professionnelles) }\end{array}$ & 0.154 & 0.256 & 0.648 & 0.117 & 0.105 & 0.282 & -0.029 & 1.003 \\
\hline $\begin{array}{l}\text { Lower secondary school } \\
\text { (bepc-diplôme national } \\
\text { du brevet) }\end{array}$ & 0.065 & 0.071 & 0.689 & 0.068 & 0.060 & 0.243 & 0.012 & 1.001 \\
\hline $\begin{array}{l}\text { Certificate of primary } \\
\text { education (cep - certificat } \\
\text { d'études primaires) }\end{array}$ & 0.122 & 0.097 & 0.666 & 0.097 & 0.062 & 0.266 & -0.003 & 1.001 \\
\hline Without any diploma & 0.171 & 0.296 & 0.724 & 0.129 & 0.186 & 0.295 & -0.034 & 1.007 \\
\hline \multicolumn{9}{|l|}{ Profession } \\
\hline $\begin{array}{l}\text { Craftsmen, shopkeepers } \\
\text { and managers }\end{array}$ & 0.093 & 0.051 & 0.670 & 0.118 & 0.055 & 0.180 & 0.110 & 1.001 \\
\hline $\begin{array}{l}\text { Executives, senior intellec- } \\
\text { tual workers }\end{array}$ & 0.225 & 0.542 & 0.737 & 0.071 & 0.797 & 0.214 & 0.130 & 1.009 \\
\hline Middle-ranking professions & 0.058 & 0.362 & 0.680 & 0.035 & 0.308 & 0.248 & 0.047 & 1.001 \\
\hline Employees & 0.104 & 0.412 & 0.700 & 0.073 & 0.269 & 0.259 & -0.001 & 1.003 \\
\hline Blue-collar workers & 0.210 & 0.234 & 0.684 & 0.151 & 0.097 & 0.319 & -0.059 & 1.005 \\
\hline Farmers, farm workers & 0.559 & 0.024 & 0.461 & 0.298 & 0.001 & 0.252 & 0.207 & 1.000 \\
\hline
\end{tabular}




\begin{tabular}{|c|c|c|c|c|c|c|c|c|}
\hline \multirow[b]{2}{*}{ Indicators } & \multicolumn{3}{|c|}{ Île-de-France } & \multicolumn{5}{|c|}{ Paris } \\
\hline & 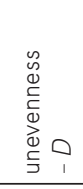 & 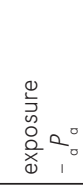 & 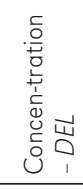 & 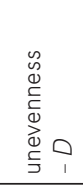 & 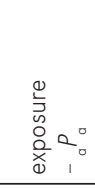 & 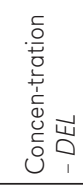 & 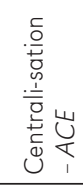 & 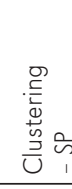 \\
\hline \multicolumn{9}{|l|}{ Unemployment } \\
\hline Unemployed & 0.123 & & 0.739 & 0.079 & & 0.267 & 0.005 & 1.002 \\
\hline \multicolumn{9}{|l|}{ Immigrants 2009} \\
\hline Immigrants & 0.171 & 0.208 & 0.779 & 0.057 & 0.207 & 0.238 & 0.096 & 1.002 \\
\hline \multicolumn{9}{|l|}{ Foreigners 2009} \\
\hline Foreigners & 0.195 & 0.156 & 0.785 & 0.066 & 0.154 & 0.239 & 0.119 & 1.002 \\
\hline
\end{tabular}

